FULL TEXT ARTICLE

REVIEW

\title{
Empagliflozin: a new sodium-glucose co-transporter 2 (SGLT2) inhibitor for the treatment of type 2 diabetes
}

\author{
Joshua J Neumiller \\ Department of Pharmacotherapy, College of Pharmacy, Washington State University, Spokane, WA, USA
}

\section{Citation}

Neumiller JJ. Empagliflozin: a new sodium-glucose cotransporter 2 (SGLT2) inhibitor for the treatment of type 2 diabetes. Drugs in Context 2014; 3: 212262. doi: 10.7573/ dic. 212262

\section{Copyright}

(c) 2014 Neumiller JJ. This is an open-access article distributed under the terms of the Creative Commons Attribution License Deed CC BY NC ND 3.0 which allows anyone to copy, distribute, and transmit the article provided it is properly attributed in the manner specified below. No other uses without permission.

\section{Correct attribution}

Copyright @ 2014 Neumiller JJ. Published by Drugs in Context under Creative Commons Attribution License Deed CC BY NC ND 3.0. http://dx.doi.org/10.7573/dic.212262

\section{Article URL}

http://www.drugsincontext.com/empagliflozin-a-newsodium-glucose-co-transporter-2-sglt2-inhibitor-for-thetreatment-of-type-2-diabetes/

\section{Correspondence}

Joshua J Neumiller. Assistant Professor, Department of Pharmacotherapy, College of Pharmacy, Washington State University, PO Box 1495, Spokane, WA 99218, USA.

jneumiller@wsu.edu

\section{Provenance}

Submitted, externally peer reviewed

\section{Dates}

Submitted: 4 March 2014

Accepted, subject to peer review: 5 March 2014

Revised manuscript submitted: 28 May 2014

Published: 11 June 2014

\section{Publisher \& contact information}

Drugs in Context is published by Just Medical Media Ltd, 11 Redgrove Park, Cheltenham, Gloucestershire GL51 6QY, UK; ISSN 1740-4398; Just Medical Media Limited is registered in England Number 6891187; VAT GB 945171322

\section{Julia Savory}

Head of Digital Publishing and Submissions Management julia@justmedicalmedia.com; Tel: +44 (0)1242910999

\section{Abbreviations}

$\mathrm{AE}$, adverse event; bid, twice daily; $\mathrm{Cl}$, confidence interval; CKD, chronic kidney disease; CV, cardiovascular; DPP-4, dipeptidyl-peptidase-4; eGFR, estimated glomerular filtration rate; EMA, European Medicines Agency; FDA, Food and Drug Administration; FDC, fixed-dose combination; FPG, fasting plasma glucose; GLP-1, glucagon-like peptide 1; GLUT, glucose transporter; HbA1c, glycosylated hemoglobin; MI, myocardial infarction; OAD, oral antidiabetes drug; OGTT, oral glucose tolerance test; PPG, post-prandial glucose; qd, once daily; SBP, systolic blood pressure; SD, standard deviation; $\mathrm{SE}$, standard error; SGLT1/2, sodium-glucose co-transporters; UGE, urinary glucose excretion; ZDF, Zucker diabetic fatty (rat). 


\section{ENDOCRINOLOGY EDITORIAL BOARD}

\section{Specialist Editor-in-Chief}

\section{Professor Eva M Vivian, PharmD}

Associate Professor, University of Wisconsin-Madison School of Pharmacy, Madison, WI, USA

\section{Specialist Health Economics Editor}

\section{Dr Won Chan Lee, PhD}

Principal, Health Economics and Outcomes Research, IMS

Consulting Group, Alexandria, VA, USA

\section{Specialist Advisor - Epidemiology}

\section{Professor Jennifer Robinson, MD}

Clinical Assistant Professor, Department of Pharmacotherapy, Washington State University College of Pharmacy, Spokane, WA, USA

\section{Specialist editorial board members}

\section{Marlon E Cerf, MD}

Specialist Scientist, Diabetes Discovery Platform, South African Medical Research Council, South Africa

\section{Pamela Daniels, MBA, MPH, PhD}

Epidemiologist, Morehouse School of Medicine, 720 Westview Drive, SW, MRC Annex S-10, Atlanta, GA, USA

\section{Professor Stuart T Haines, PharmD}

Professor and Vice Chair for Clinical Services, Department of Pharmacy Practice and Science, University of Maryland School of Pharmacy, Baltimore, MD, USA; Clinical Pharmacy Specialist, West Palm Beach VA Medical Center, West Palm Beach, FL, USA

\section{Sivaramakrishna Koganti, PhD}

Department of Internal Medicine, Carver College of Medicine, University of lowa, USA

\section{Professor Elaena Quattrocchi, PharmD}

Associate Professor, Division of Pharmacy Practice, Arnold and Marie Schwartz College of Pharmacy and Health Sciences,

Staten Island University Hospital, NY, USA

\section{Evan Sisson, PharmD, MHA, CDE}

Virginia Commonwealth University, School of Pharmacy, Virginia, USA

\section{Junhua Yu}

Assistant Professor, Social, Behavioral and Administrative Sciences,Touro University College of Pharmacy, Vallejo, CA, USA

To see the full Drugs in Context Editorial Board, please visit www.drugsincontext.com/editorial-board

\section{Group Editor-in-Chief}

\section{Christopher Blanchette, PhD, MBA}

Associate Dean for Research and Research Associate Professor in the Department of Public Health Sciences at the University of North Carolina and Director of Health Economics \& Outcomes Research at Otsuka America Pharmaceutical Inc, USA

\section{Expert Advisers - Epidemiology and biostatistics}

Alex K Exuzides, PhD

Director, ICON Clinical Research Inc, California, USA

\section{Professor Scott L Friedman, MD}

Fishberg Professor of Medicine, Dean for Therapeutic Discovery Chief, Division of Liver Diseases, Mount Sinai School of Medicine, New York, USA

\section{Carl De Moor, PhD}

Senior Principal, Epidemiology and Leader Epidemiology, Safety and Risk Management Center of Excellence Americas, IMS Health Inc, USA

\section{Dr John H Walker, OCT, MBA, PhD}

Professor, Goodman School of Business, Brock University, St Catharines, Ontario, Canada

\section{Expert Adviser - Publication Ethics}

\section{Dr Elizabeth (Liz) Wager}

Publications Consultant, Princes Risborough, UK; Visiting Professor, University of Split School of Medicine, Croatia; Former Chair (2009-2012), Committee on Publication Ethics (COPE)

\section{Editor-in-Chief Emeritus}

Dr George Kassianos, FRCGP, FESC, FBGTHA, FAcadMEd, FFTM RCPSGlasg

General Practitioner, Bracknell, Berkshire, UK; President British Global \& Travel Health Association Fellow of the European Society of Cardiology

Specialist Advisor - Clinical Pharmacology

Dr Richard White, MA, PhD

Consulting Partner and Director, Oxford PharmaGenesis Ltd, UK 


\section{Empagliflozin: a new sodium-glucose co-transporter 2 (SGLT2) inhibitor for the treatment of type 2 diabetes}

Joshua J Neumiller

Department of Pharmacotherapy, College of Pharmacy, Washington State University, Spokane, WA, USA

\section{Citation}

Neumiller JJ. Empagliflozin: a new sodium-glucose cotransporter 2 (SGLT2) inhibitor for the treatment of type 2 diabetes. Drugs in Context 2014; 3: 212262.

doi: $10.7573 /$ dic. 212262

\begin{abstract}
Type 2 diabetes is increasing in prevalence worldwide, and hyperglycemia is often poorly controlled despite a number of therapeutic options. Unlike previously available agents, sodium-glucose co-transporter 2 (SGLT2) inhibitors offer an insulin-independent mechanism for improving blood glucose levels, since they promote urinary glucose excretion (UGE) by inhibiting glucose reabsorption in the kidney. In addition to glucose control, SGLT2 inhibitors are associated with weight loss and blood pressure reductions, and do not increase the risk of hypoglycemia.
\end{abstract}

Empagliflozin is a selective inhibitor of SGLT2, providing dose-dependent UGE increases in healthy volunteers, with up to $90 \mathrm{~g}$ of glucose excreted per day. It can be administered orally, and studies of people with renal or hepatic impairment indicated empagliflozin needed no dose adjustment based on pharmacokinetics. In Phase II trials in patients with type 2 diabetes, empagliflozin provided improvements in glycosylated hemoglobin $(\mathrm{HbA} 1 \mathrm{c})$ and other measures of glycemic control when given as monotherapy or add-on to metformin, as well as reductions in weight and systolic blood pressure. As add-on to basal insulin, empagliflozin not only improved $\mathrm{HbA1c}$ levels but also reduced insulin doses. Across studies, empagliflozin was generally well tolerated with a similar rate of hypoglycemia to placebo; however, patients had a slightly increased frequency of genital infections, but not urinary tract infections, versus placebo. Phase III studies have also reported a good safety profile along with significant improvements in $\mathrm{HbA1c}$, weight and blood pressure, with no increased risk of hypoglycemia versus placebo. Based on available data, it appears that empagliflozin may be a useful option in a range of patients; however, clinical decisions will be better informed by the results of ongoing studies, in particular, a large cardiovascular outcome study (EMPA-REG OUTCOME ${ }^{\mathrm{TM}}$ ).

Keywords: Blood glucose, combination drug therapy, empagliflozin, hemoglobin A1c protein, hypertension, obesity, sodium-glucose co-transporter 2 (SGLT2) inhibitors, type 2 diabetes

\section{Introduction}

In patients with type 2 diabetes, higher levels of hyperglycemia are associated with increasing risk of vascular events, with each $1 \%$ increase in glycosylated hemoglobin ( $\mathrm{HbA} 1 \mathrm{c})$ associated with as much as $38 \%$ increased risk of mortality [1]. In patients with type 1 diabetes, intensive diabetes therapy has been clearly shown to reduce the incidence of clinical cardiovascular events including myocardial infarction, stroke, and cardiac death. In type 2 diabetes, the relationship between therapeutic reduction of $\mathrm{HbA} 1 \mathrm{c}$ and mortality risk has not been so clearly demonstrated, but good glycemic control undoubtedly reduces the risk of microvascular outcomes such as retinopathy, neuropathy, and nephropathy, with possible long-term effects on cardiovascular outcomes such as myocardial infarction
[2-4]. Effective glycemic control is therefore considered central to patient management, and a number of glucose-lowering therapies are available. Yet in clinical practice many patients do not achieve glycemic goals [5]. The most frequently cited reason is the side-effect profiles of available agents, in particular hypoglycemia and weight gain, although unwillingness to begin insulin injections may also play a role $[6,7]$. Furthermore, many patients do not maintain individualized glycemic goals, due to the natural progression of type 2 diabetes [8]. Novel antihyperglycemic therapies are therefore intensively sought, with recent success in the area of promoting glucose excretion [9]. Until recently, preventing urinary glucose excretion (UGE) was thought a measure of diabetes control, but this shift to considering UGE as a therapeutic strategy has led to the development of a whole new class of drugs for glucose 
control; namely, the sodium-glucose co-transporter 2 (SGLT2) inhibitors or 'gliflozins', which promote UGE by inhibiting glucose reabsorption in the kidney [9]. This review considers the mechanism of gliflozins, before reviewing the available evidence for a gliflozin currently in late-stage development, empagliflozin.

\section{Glucose reabsorption in healthy people}

The kidneys are crucial for maintaining glucose homeostasis, and contribute to this process via glucose uptake, gluconeogenesis, and reabsorption of glucose from the glomerular filtrate into the circulation $[10,11]$. On average, an individual's entire blood volume is filtered by the kidney more than 50 times daily, with around $160-180 \mathrm{~g}$ of glucose filtered from plasma by glomeruli every day $(180 \mathrm{~L}$ per day at approximately $100 \mathrm{mg} / \mathrm{dL}$ of glucose) [12]. Under normal circumstances, this filtered glucose is almost completely reabsorbed in the proximal tubules of the kidney, leaving the urine free of glucose.

The reabsorption of filtered glucose is mediated by SGLTs, a family of active, sodium-dependent, large trans-membrane proteins [13]. Two members of the SGLT family are involved in glucose reabsorption in the kidney: SGLT2 is a high-capacity, lowaffinity transporter, expressed in the early convoluted segment of the proximal tubule, and has traditionally been thought to be responsible for nearly $90 \%$ of the active renal glucose reabsorption [14-17]; while SGLT1, a high-affinity, low-capacity transporter, expressed in the distal segment of the proximal tubule, reabsorbs the remaining $10 \%$ (Figure 1) $[14,17]$. SGLT2 is thought to be expressed exclusively in renal proximal tubules, but SGLT1 is also found in the gastrointestinal tract, where it is responsible for absorption of galactose as well as glucose $[15,18]$. For both SGLTs, glucose reabsorbed from the proximal tubules by SGLTs is then passively diffused into the circulation via facilitative glucose transporters (GLUTs) at the basolateral membrane of the cells lining the proximal tubule [11].

\section{Glucose reabsorption in people with type 2 diabetes}

In patients with type 2 diabetes, blood glucose levels eventually become so high that they exceed the capacity of the SGLT2 transporters, at a threshold of approximately $200 \mathrm{mg} / \mathrm{dL}$ (11.0 $\mathrm{mmol} / \mathrm{L}$ ) [19]. Thus, not all glucose is reabsorbed, and glucose begins to appear in the urine. Unfortunately, in patients with ongoing hyperglycemia, up-regulation of glucose transporter genes increases the level of renal glucose reabsorption [20]. This increased threshold for glucose transport minimizes UGE and intensifies hyperglycemia [10,19,21]; however, once this increased threshold is exceeded, the characteristic glucosuria is detected.

In recent years, realistic options for promoting UGE via SGLT inhibition have been identified. Efforts have focused on selective SGLT2 inhibition, as this transporter is expressed almost exclusively in renal proximal tubules and its inhibition is
Figure 1. Antidiabetic mechanism of SGLT2 inhibitors.

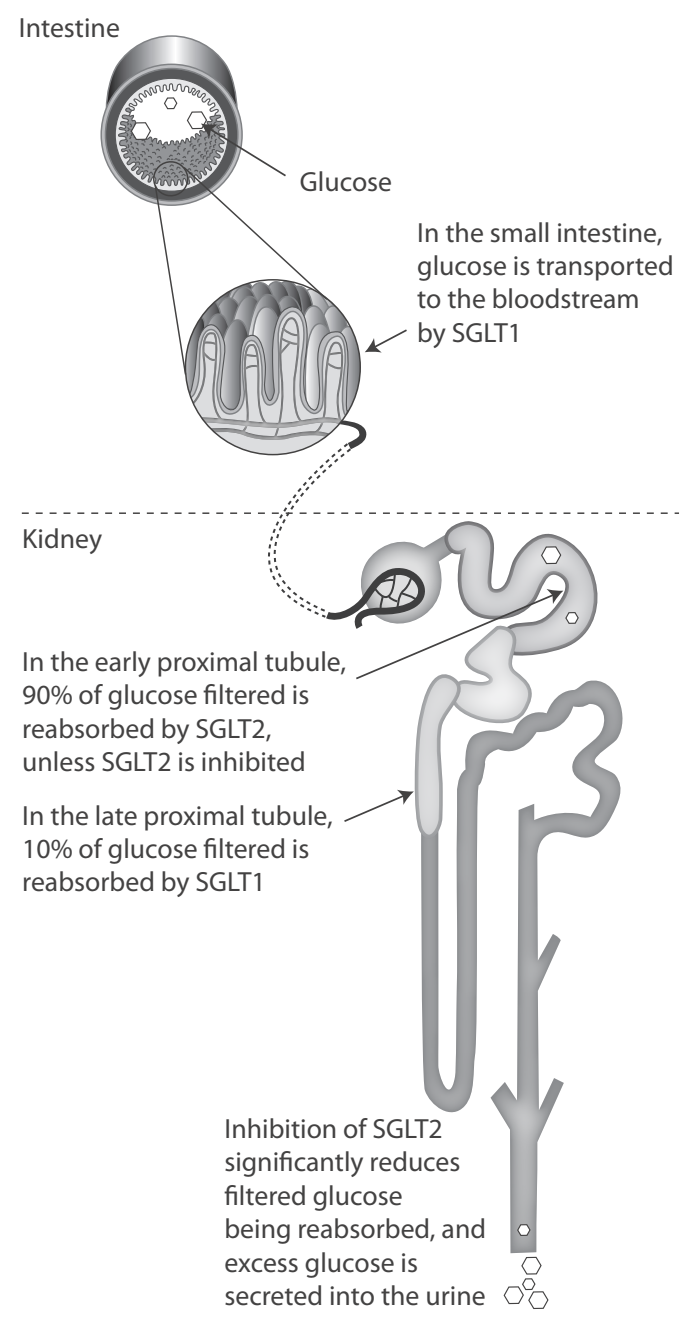

SGLT, sodium-glucose co-transporter.

doi: 10.7573/dic.212262.f001

therefore unlikely to affect other organ systems [18]. Individuals who lack functional SGLT1 have severe gastrointestinal symptoms due to malabsorption of glucose and galactose [22], while people who lack a functional gene for SGLT2 generally lead normal healthy lives, despite the presence of higher-thannormal levels of glucose in their urine [23]. In people lacking SGLT2 (a condition known as familial renal glycosuria), essential levels of glucose are maintained, and although SGLT2 normally transports around $90 \%$ of the $180 \mathrm{~g}$ of glucose reabsorbed, inhibition of SGLT2 typically only results in maximum excretion of about $50 \%$ ( $90 \mathrm{~g}$ ) of glucose, suggesting that when SGLT2 is inhibited, SGLT1 capacity can be increased [12]. Besides reduction in blood glucose, SGLT2 inhibition has the additional potential advantages of weight loss (corresponding to the calories lost daily in excreted glucose) as well as no increase in hypoglycemia (since insulin secretion is not stimulated) when used as monotherapy.

Phlorizin, a compound originally isolated from the bark of apple trees, was the first SGLT inhibitor identified. Despite 
its ability to induce glucosuria, phlorizin was not clinically developed because it had low bioavailability, degraded rapidly after oral administration to phloretin (a potent inhibitor of GLUT transporters), and inhibited SGLT1 (with consequent gastrointestinal side effects) $[24,25]$. It nevertheless provided a structural foundation for the development of other compounds with greater bioavailability following oral administration and higher selectivity for SGLT2. The structure of phlorizin consists of a glucose ring and two aromatic rings joined by a glycosidic oxygen [26]. Analogs containing O-glucoside were initially developed; however, these compounds were still susceptible to hydrolysis by glucosidases in the intestine. C-glucosides proved more metabolically robust, and the glucoside-based SGLT2 inhibitors currently in various phases of clinical development all use a C-aryl linkage [27]. A number of compounds have reached Phase III clinical trials: two (canagliflozin and dapagliflozin) have been approved for use in type 2 diabetes by the European Medicines Agency (EMA) and the Food and Drug Administration (FDA). A third SGLT2 inhibitor, empagliflozin, was approved for use in type 2 diabetes by the EMA in May 2014, and an application to the FDA is pending. Thus, this is a useful time to review the early therapeutic studies of the empagliflozin clinical development program, focusing on the mechanism of action and dose-ranging studies, as well as the trials that are currently ongoing.

\section{Empagliflozin in preclinical studies}

The chemical compound BI 10773 that was developed by Boehringer Ingelheim Pharmaceuticals (Ingelheim, Germany) and later named empagliflozin (pronounced em" pa gli floe'zin) [28], uses a C-glucoside-based structure. In vitro, empagliflozin has been shown to be a potent and highly specific SGLT2 inhibitor, with >2500-fold selectivity towards SGLT2 (IC $_{50} 3.1$ $\mathrm{nM}$ ) in comparison with SGLT1 (IC $8300 \mathrm{nM})$ [29], which suggests that the renal pharmacologic response would be solely mediated by SGLT2 [27]. In comparison, IC 50 values for canagliflozin are $2.7 \mathrm{nM}$ for SGLT2 and $710 \mathrm{nM}$ for SGLT1, while $\mathrm{IC}_{50}$ values for dapagliflozin are $1.2 \mathrm{nM}$ (SGLT2) and $1400 \mathrm{nM}$ (SGLT1), for which a transient effect on SGLT1 in the gut might be predicted while the compound is at very high concentration due to oral absorption. In a tracer study in 20 healthy people, canagliflozin appeared to reduce the rate of oral glucose absorption, which the investigators thought likely to be due to intestinal SGLT1 inhibition, but this requires

further investigation [30].

In animal model studies using Zucker diabetic fatty (ZDF) rats, single doses of empagliflozin of 1 or $3 \mathrm{mg} / \mathrm{kg}$ or vehicle (placebo) resulted in dose-dependent increases in UGE, and 5 weeks of treatment with $0.3,1$, or $3 \mathrm{mg} / \mathrm{kg}$ empagliflozin or vehicle reduced levels of fasting plasma glucose (FPG) and $\mathrm{HbA} 1 \mathrm{C}$, and improved glucose tolerance in response to glucose challenge [31]. During the study, there was no sign of hypoglycemia, and insulin sensitivity was also increased [31].
In an 8-week study in ZDF rats, empagliflozin $3 \mathrm{mg} / \mathrm{kg}$ oncedaily provided sustained glycemic responses and also showed improvement in beta-cell mass, raising the possibility that empagliflozin could preserve pancreatic function [32]. In dietaryinduced obese rats, empagliflozin resulted in a significant increase in UGE as well as significant weight losses after 4 weeks ( $4.1 \%$ of body weight with empagliflozin $3 \mathrm{mg} / \mathrm{kg}$ once-daily and $6.9 \%$ with $10 \mathrm{mg} / \mathrm{kg}$, both significant versus placebo) [33]. There were no changes in body water or protein content, confirming loss of fat accounted for the majority of the observed weight loss. These preclinical data indicated that empagliflozin showed promise for the treatment of type 2 diabetes in humans, and clinical investigations ensued, following the standardized phases of a clinical development program.

\section{Pharmacokinetic, pharmacodynamics, safety, and drug-drug interaction studies}

An initial study of empagliflozin was designed to evaluate the safety, tolerability, pharmacokinetics, and pharmacodynamics of single escalating doses of empagliflozin in 72 healthy male volunteers [34]. Subjects were recruited at a single center in Germany: eight subjects were randomized to each dose of empagliflozin $(0.5,2.5,10,25,50,100,200,400$ or $800 \mathrm{mg})$, and within each dose two subjects received placebo in a doubleblinded fashion. Participants in the 50-mg group also took part in an oral glucose tolerance test (OGTT). Pharmacokinetic analyses showed empagliflozin was rapidly absorbed after oral administration, with a median $\mathrm{t}_{\max }$ ranging from 1.5 to 2.1 hours across the dose groups. Plasma levels declined in a biphasic fashion with a rapid distribution phase and a slower elimination phase. Exposure to empagliflozin was approximately doseproportional over the range of $0.5-800 \mathrm{mg}$. The terminal elimination half-life was up to 13.1 hours, and renal clearance over 72 hours ranged from $32.1 \mathrm{~mL} / \mathrm{min}$ to $51.3 \mathrm{~mL} / \mathrm{min}$. The majority of empagliflozin was excreted via the urine in the first 24 hours, with approximately $11-19 \%$ of the administered dose excreted unchanged.

All doses of empagliflozin inhibited reabsorption of glucose in the urine, with empagliflozin doses up to $10 \mathrm{mg}$ inhibiting reabsorption of up to $40 \%$ of filtered glucose, while higher doses inhibited reabsorption of $40-60 \%$ of filtered glucose (translating to a maximum of $90 \mathrm{~g}$ of glucose). The total amount of glucose excreted over 72 hours increased with dose, reaching a plateau at around the $100 \mathrm{mg}$ empagliflozin dose. As expected in healthy people, plasma glucose levels were similar among participants treated with any dose of empagliflozin or placebo (since the liver compensates by increasing glucose production to prevent hypoglycemia), and in the OGTT, $75 \mathrm{~g}$ of glucose had no relevant effects on the pharmacokinetics of empagliflozin. The number of subjects experiencing an adverse event (AE) was similar for the empagliflozin and placebo groups, and no safety concerns were identified. 
A Phase I study with a similar design was used to investigate dose-response relationships in 48 healthy Japanese men [35]. Again, eight subjects were randomized to each empagliflozin dose tested $(1,5,10,25$, and $100 \mathrm{mg}$, with a second group receiving $10 \mathrm{mg}$ with an OGTT). As in the Caucasian subjects, empagliflozin was well tolerated with dose-proportional exposure, and showed increased UGE with increasing drug dose. Exposure was approximately 1.5-fold higher, which the study investigators thought likely due to the differences in body weights between the populations (the median body weight was $20 \%$ lower in the Japanese volunteers than in the German group). It appeared, however, that the exposure did not affect levels of UGE, with similar levels at corresponding empagliflozin doses, establishing that the same therapeutic dose could be used in this population.

The effect of food on the bioavailability of empagliflozin absorption was investigated in an open-label, randomized, cross-over study in 14 healthy male volunteers [34]. Subjects received $50 \mathrm{mg}$ empagliflozin after an overnight fast of at least 10 hours or immediately after consumption of a highfat, high-calorie meal. There were no differences in AE profiles when empagliflozin was given with or without food, and food produced no clinically relevant effects on drug exposure, indicating that empagliflozin is suitable for once-daily administration independent of meal timing.

Patients with type 2 diabetes are frequently prescribed multiple medications to achieve glycemic, blood pressure, lipid, and other individualized treatment goals [36]. Accordingly, empagliflozin has been tested in combination with other drugs commonly used in people with type 2 diabetes, including other glucose-lowering agents (metformin [37], sitagliptin [38], linagliptin [39], glimepiride [40]), an anticoagulant (warfarin [41]), cardiovascular/antihypertensive medicines (the diuretics hydrochlorothiazide or torasemide [42], verapamil, ramipril, digoxin [43]), and a cholesterol-lowering agent (simvastatin [44]). These drug-drug interaction studies were all open-label, cross-over trials performed in healthy volunteers, apart from the investigation with diuretics, which was carried out in patients with type 2 diabetes. Furthermore, as oral contraceptives may be co-administered with antidiabetes agents, the interaction of empagliflozin with a combined oral contraceptive was also investigated in healthy female volunteers [45]. No clinically relevant effects occurred following co-administration of empagliflozin with any of the above-listed medications, and it was concluded that empagliflozin may be co-administered with these medications without the need for dosage adjustments. A randomized, double-blind, placebo-controlled study in 30 healthy volunteers also showed that neither a single therapeutic dose of empagliflozin $(25 \mathrm{mg})$ nor a supratherapeutic dose $(200 \mathrm{mg}$ ) were associated with prolongation of cardiac repolarization (as measured by the QT interval) or heart rate [46]. Again, empagliflozin doses were well tolerated in these subjects.
Following these successful studies in healthy volunteers, trials were designed to investigate the safety, tolerability, pharmacokinetics, and pharmacodynamics of empagliflozin in patients with type 2 diabetes. A randomized, double-blind, placebo-controlled study investigated multiple escalating doses of empagliflozin ( $2.5 \mathrm{mg}$ to $100 \mathrm{mg}$ once daily) over 8 days in patients with type 2 diabetes [47]. A total of 48 patients were randomized to one of four doses of empagliflozin $(2.5,10,25$, or $100 \mathrm{mg}$ once daily) or placebo; in each group, nine patients received active drug and three received placebo. Empagliflozin was well tolerated with approximately dose-proportional exposure and resulted in clinically meaningful increases in UGE, ranging from $77.9 \mathrm{mg}$ after a single dose of empagliflozin $10 \mathrm{mg}$, to $89.8 \mathrm{~g}$ with empagliflozin $100 \mathrm{mg}$. These results were consistent with those of a similar study, also in patients with type 2 diabetes but with a 4-week duration, in which 78 patients were randomized to empagliflozin 10, 25, or $100 \mathrm{mg}$ or placebo [48]. The patients also had an OGTT at the start and end of the study. By Day 1, UGE increased with empagliflozin treatment ( $74 \mathrm{~g}$ in the $10-\mathrm{mg}$ group, $90 \mathrm{~g}$ in the $25-\mathrm{mg}$ group and $81 \mathrm{~g}$ in the 100-mg group, compared with no significant change in the placebo group), and increased UGE was maintained throughout the study. Significant improvements in FPG were also observed and in post-OGTT blood glucose levels compared with the start of the study. Empagliflozin was well tolerated in this study, with similar proportions of patients in empagliflozin and placebo groups experiencing AEs. These results were further supported by a 4-week study of empagliflozin in Japanese patients with type 2 diabetes, in which 100 patients were randomized to receive $1,5,10$, or 25 $\mathrm{mg}$ of empagliflozin, or placebo, once daily [49]. After 4 weeks, all empagliflozin groups showed significant increases in UGE ( $40.8 \mathrm{~g}, 77.1 \mathrm{~g}, 80.9 \mathrm{~g}$, and $93.0 \mathrm{~g}$ versus $-2.1 \mathrm{~g}$ for placebo), and empagliflozin was well tolerated.

A significant proportion of patients with type 2 diabetes have renal impairment, and as renal function can affect drug pharmacokinetics and pharmacodynamics, a single dose of empagliflozin (50 mg) was tested in an open-label, parallelgroup study conducted at two European centers [50]. Forty subjects were recruited: a control group of eight subjects with type 2 diabetes and normal renal function (estimated glomerular filtration rate $[\mathrm{eGFR}]>90 \mathrm{~mL} / \mathrm{min} / 1.73 \mathrm{~m}^{2}$ ); nine subjects with type 2 diabetes and mild renal impairment (eGFR 60-89 mL/min/1.73 $\mathrm{m}^{2}$ ); seven with type 2 diabetes and moderate renal impairment (eGFR 30-59 mL/min/1.73 m²); eight with severe renal impairment (eGFR $<30 \mathrm{~mL} / \mathrm{min} / 1.73 \mathrm{~m}^{2}$ ), four of whom also had type 2 diabetes, and eight subjects with renal failure/end-stage renal disease requiring dialysis (none of whom had type 2 diabetes). Pharmacokinetic properties of empagliflozin were largely unaltered by renal impairment, suggesting that no dose adjustments are required in patients with renal impairment. As expected, exposure to empagliflozin increased moderately with increasing renal impairment, thought to be due to decreased clearance of empagliflozin. 
This decreased clearance could offset the reduced protein binding in patients with renal impairment, suggesting clinically meaningful reductions in plasma glucose levels could be expected with empagliflozin even in patients with moderate renal impairment.

The effect of hepatic impairment on the pharmacokinetics, safety, and tolerability of empagliflozin has also been studied in an open-label trial [51]. Volunteers with varying degrees of hepatic impairment (but not with type 2 diabetes) were enrolled (eight each with mild, moderate, or severe hepatic impairment and 12 matched controls with normal hepatic function); all were given a single dose of empagliflozin $50 \mathrm{mg}$, double the maximum planned therapeutic dose. In the patients with hepatic impairment, increases in empagliflozin exposure were less than 2-fold exposure in those with normal hepatic function, and the drug was well tolerated, indicating that it can also be used without dose adjustment in this population.

\section{Phase II studies (safety data and further exploratory efficacy data)}

In the Phase I studies described above, empagliflozin was well tolerated and appeared promising in terms of glucose improvements and thus was entered into Phase II trials, including three studies of 12-week duration, and two longer-term studies.

To assess empagliflozin as monotherapy, a Phase II, randomized, double-blind, placebo-controlled trial evaluated the efficacy, safety, tolerability, and pharmacokinetics of empagliflozin (5, 10 , and $25 \mathrm{mg}$ once daily) in patients with type 2 diabetes over 12 weeks [52]. As well as a placebo control arm, the study also included an open-label metformin arm (1000 mg twice-daily, or maximum tolerated dose). Steady-state concentrations of empagliflozin were maintained throughout the 12-week duration of the study, and increased in proportion to dose. By 12 weeks, empagliflozin induced a dose-dependent and statistically significant reduction in $\mathrm{HbA} 1 \mathrm{c}$ compared with placebo (Table 1). Furthermore, the decreases in FPG and $\mathrm{HbA} 1 \mathrm{c}$ that occurred with $25 \mathrm{mg}$ empagliflozin appeared similar to those obtained with the maximum tolerated dose of metformin [52]. The mean weight loss in the three empagliflozin groups ranged between 1.8 and $2.3 \mathrm{~kg}$ (Table 1), and the agent was well tolerated, with no reports of hypoglycemia (Table 2).

Metformin is currently recommended as the first-line treatment for patients with type 2 diabetes, thus, in clinical practice, empagliflozin would likely be used as an add-on therapy to metformin. Consequently, the safety and efficacy of empagliflozin $(1,5,10,25$, and $50 \mathrm{mg}$ once daily) has also been investigated in patients with type 2 diabetes who were inadequately controlled on metformin [53]. A Phase II, randomized, double-blind, placebo-controlled study was conducted - also 12 weeks in duration and including an open-label sitagliptin $100 \mathrm{mg}$ once daily arm. When compared with placebo, all empagliflozin doses except $1 \mathrm{mg}$ showed significant and dose-dependent reductions in $\mathrm{HbA} 1 \mathrm{c}$ and body weight (Table 1). Empagliflozin was generally well tolerated with a slightly increased frequency of genital infections, but not urinary tract infections, when compared with placebo (Table 2).

Furthermore, a pooled analysis of data ( $10 \mathrm{mg}$ and $25 \mathrm{mg}$ dose groups) from these two Phase II studies assessed blood pressure changes from baseline after 12 weeks of treatment [54]. Systolic blood pressure (SBP) decreased by $4-5 \mathrm{mmHg}$ with empagliflozin, and the change was significant versus placebo for each dose group. The changes appeared to be greater among patients with SBP $>140 \mathrm{mmHg}$ at baseline. Diastolic blood pressure changes were not statistically significant when compared with placebo.

Patients from the preceding two studies also participated in an open-label extension study for an additional 78 weeks [55]. Patients randomized to 1, 5, or $50 \mathrm{mg}$ of empagliflozin or placebo in the preceding trial were re-randomized to 10 or 25 mg empagliflozin, while those previously randomized to $10 \mathrm{mg}$ or 25 mg empagliflozin, metformin, or sitagliptin continued with the same treatment. Patients who did not switch at the start of the extension study therefore had a total of 90 weeks on continuous treatment. These patients had sustained reductions in $\mathrm{HbA} 1 \mathrm{c}, \mathrm{FPG}$, and weight. Of all patients in the 78-week extension (including 'switching' as well as 'continuing' patients), AEs were reported at a similar rate across groups, and the majority were mild or moderate. Hypoglycemic events were reported in $0.9-2.4 \%$ of patients on empagliflozin, 3.6\% on metformin monotherapy, and $3.6 \%$ on sitagliptin add-on to metformin. Adverse events related to urinary tract infections were reported in $3.8-12.7 \%$ of patients on empagliflozin, 3.6\% on metformin, and $12.5 \%$ on sitagliptin, and AEs related to genital infections were reported in $3.0-5.5 \%$ of patients on empagliflozin, $1.8 \%$ on metformin, and none on sitagliptin.

The long-term efficacy and safety of empagliflozin has also been investigated as add-on therapy to basal insulin [56]. Patients with type 2 diabetes were randomized to empagliflozin $10 \mathrm{mg}$ or $25 \mathrm{mg}$ once daily or placebo; the basal insulin regimen was kept constant for the first 18 weeks, after which the treating investigator could adjust the regimen at their discretion for the following 60 weeks. As well as significant improvements in HbA1c (Table 1), patients in both empagliflozin groups had significant reductions in their insulin doses at week 78, and also experienced weight losses versus a small weight gain in those participants receiving placebo.

As in earlier clinical development, empagliflozin was tested in a dose-finding study in Japanese patients with type 2 diabetes [57]. This randomized, placebo-controlled, double-blind study evaluated the efficacy and tolerability of empagliflozin monotherapy ( $5 \mathrm{mg}, 10 \mathrm{mg}, 25 \mathrm{mg}$, and $50 \mathrm{mg}$ once daily) for 12 weeks. All doses of empagliflozin tested led to significant improvements in glycemic control and body weight; improvements in blood pressure were also observed 


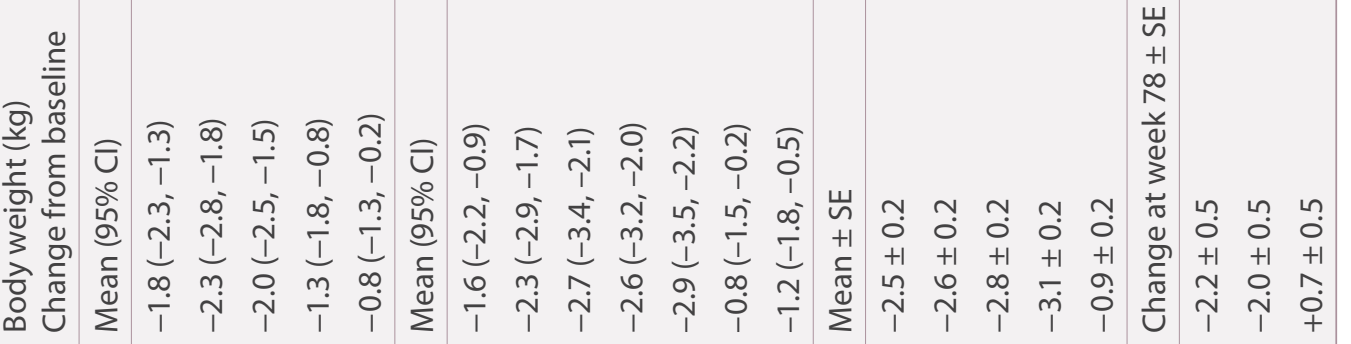

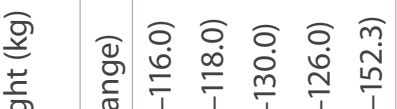

苟

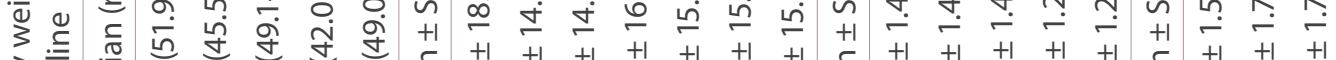
武考 ○

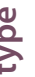

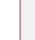

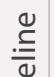

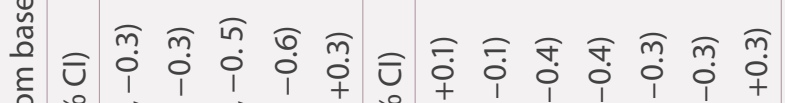

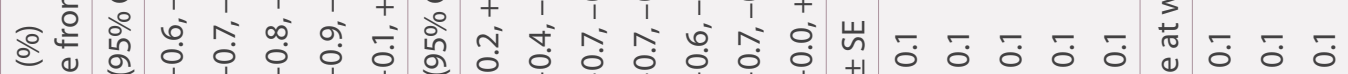

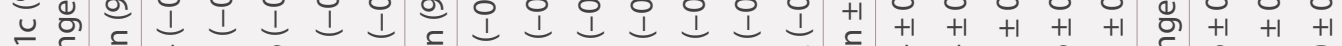

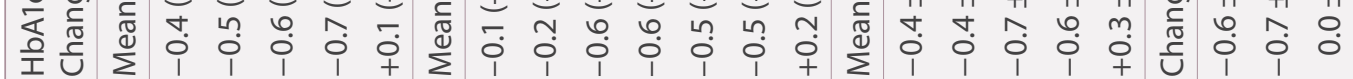
(1)

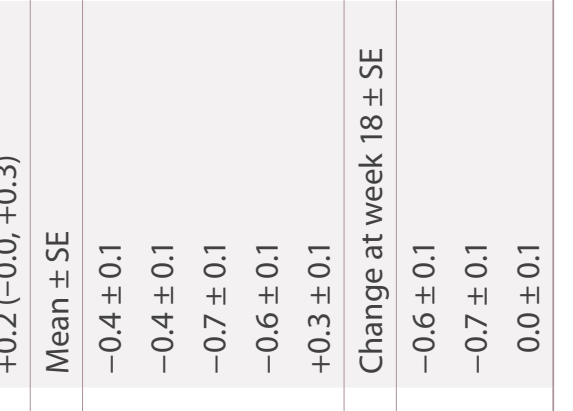

동

है

ஓ

岃

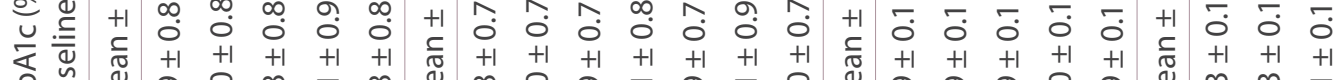
高

$\stackrel{4}{n}$

잉

¿
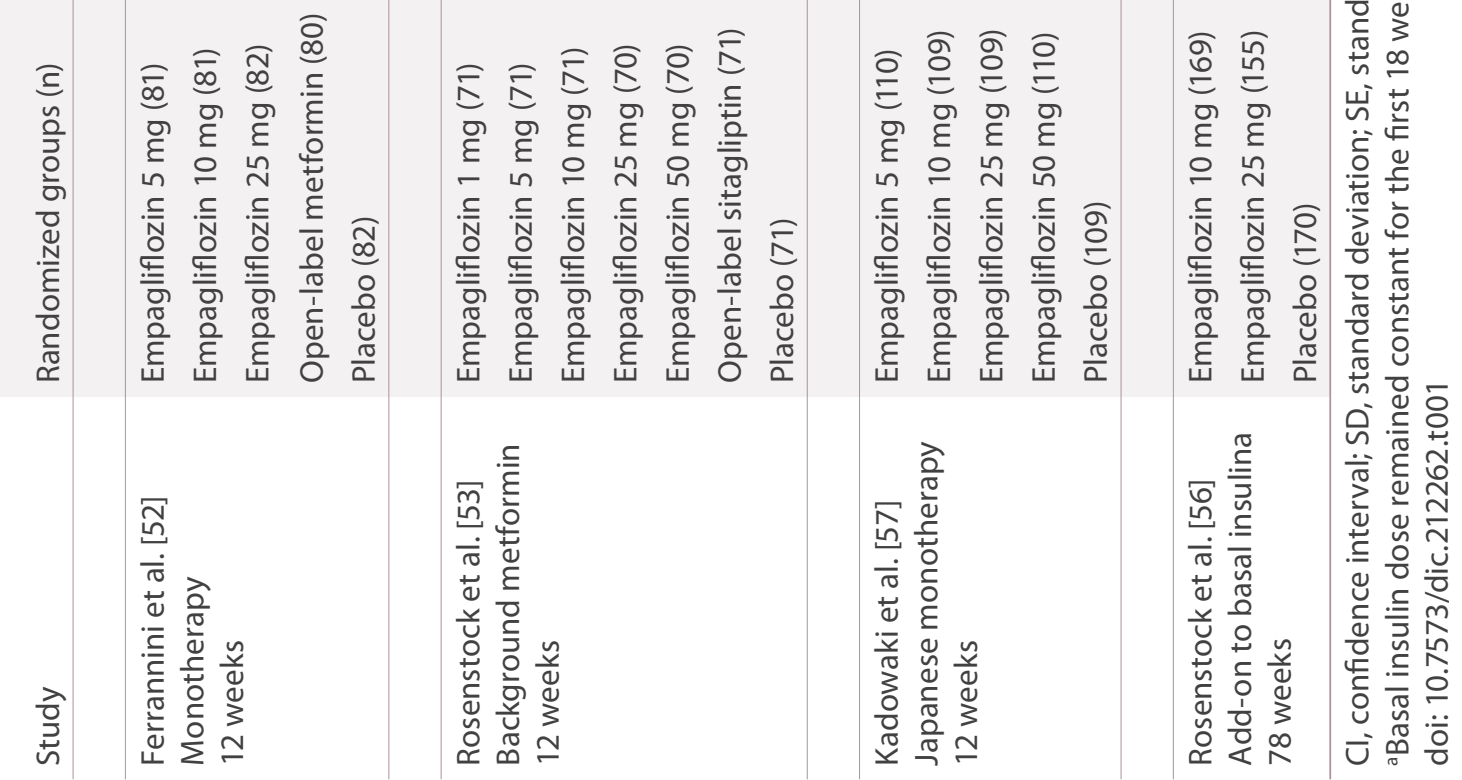
Table 2. Safety events of special interest in Phase II, randomized, controlled trials for empagliflozin.

\begin{tabular}{|c|c|c|c|c|}
\hline Study & Randomized groups (n) & $\begin{array}{l}\text { Hypoglycemia } \\
\text { n (\%) }\end{array}$ & $\begin{array}{l}\text { Urinary tract } \\
\text { infections } \\
\mathrm{n}(\%)\end{array}$ & $\begin{array}{l}\text { Genital infections } \\
\mathrm{n}(\%)\end{array}$ \\
\hline \multirow{5}{*}{$\begin{array}{l}\text { Ferrannini et al. [52] } \\
\text { Monotherapy } \\
12 \text { weeks }\end{array}$} & Empagliflozin 5 mg (81) & 0 & $2(2.5)$ & 0 \\
\hline & Empagliflozin 10 mg (81) & 0 & $1(1.2)$ & $3(3.7)$ \\
\hline & Empagliflozin 25 mg (82) & 0 & $1(1.2)$ & $2(2.4)$ \\
\hline & Open-label metformin (80) & $1(1.2)$ & $2(2.5)$ & 0 \\
\hline & Placebo (82) & $1(1.2)$ & $1(1.2)$ & 0 \\
\hline \multirow{7}{*}{$\begin{array}{l}\text { Rosenstock et al. [53] } \\
\text { Background metformin } \\
12 \text { weeks }\end{array}$} & Empagliflozin 1 mg (71) & 0 & $2(2.8)$ & $1(1.4)$ \\
\hline & Empagliflozin 5 mg (71) & $3(4.2)$ & $2(2.8)$ & $4(5.6)$ \\
\hline & Empagliflozin 10 mg (71) & 0 & $3(4.2)$ & $7(9.9)$ \\
\hline & Empagliflozin 25 mg (70) & 0 & $4(5.7)$ & 0 \\
\hline & Empagliflozin 50 mg (70) & $1(1.4)$ & $3(4.3)$ & $2(2.9)$ \\
\hline & Open-label sitagliptin (71) & $2(2.8)$ & $3(4.2)$ & $2(2.8)$ \\
\hline & Placebo (71) & 0 & $2(2.8)$ & 0 \\
\hline \multirow{5}{*}{$\begin{array}{l}\text { Kadowaki et al. [57] } \\
\text { Japanese monotherapy } \\
12 \text { weeks }\end{array}$} & Empagliflozin 5 mg (110) & 0 & 0 & $1(0.9)$ \\
\hline & Empagliflozin 10 mg (109) & 0 & $1(0.9)$ & $1(0.9)$ \\
\hline & Empagliflozin 25 mg (109) & $1(0.9)$ & $1(0.9)$ & 0 \\
\hline & Empagliflozin 50 mg (110) & $1(0.9)$ & $1(0.9)$ & $1(0.9)$ \\
\hline & Placebo (109) & 0 & $1(0.9)$ & 0 \\
\hline \multirow{3}{*}{$\begin{array}{l}\text { Rosenstock et al. [56] } \\
\text { Add-on to basal insulin } \\
78 \text { weeks }\end{array}$} & Empagliflozin 10 mg (169) & $36.1 \%$ & $14.8 \%$ & $7.7 \%$ \\
\hline & Empagliflozin 25 mg (155) & $36.1 \%$ & $11.6 \%$ & $5.2 \%$ \\
\hline & Placebo (170) & $35.3 \%$ & $8.8 \%$ & $1.8 \%$ \\
\hline
\end{tabular}

${ }^{a}$ Basal insulin dose remained constant for the first 18 weeks, then adjustments were allowed at investigator discretion; the primary endpoint was measured at 18 weeks.

doi: 10.7573/dic.212262.t002

but not statistically assessed for significance. Safety results have not yet been reported in detail, but hypoglycemia was rare, reported in one patient receiving empagliflozin $25 \mathrm{mg}$ and one patient receiving empagliflozin $50 \mathrm{mg}$, with no events requiring assistance. Adverse events consistent with urinary tract infection or genital infection were reported in less than $1 \%$ of patients, and the investigators concluded that based on benefit-risk assessment, $10 \mathrm{mg}$ and $25 \mathrm{mg}$ once daily were appropriate empagliflozin doses for subsequent Phase III trials.

\section{Beyond Phase II: pivotal trials and post-marketing studies}

Phase III trials are often referred to as pivotal, as they provide the evidence for the safety and efficacy of the drug needed to gain its approval for marketing. As with all diabetes therapies, a large program of Phase III trials is required to demonstrate the efficacy and safety of empagliflozin as monotherapy, as initial combination with other agents, or as add-on therapy to stable doses of various other agents. At the time of writing, 12 Phase III trials for empagliflozin are listed on the US National Institutes of Health clinical trials registry (www.clinicaltrials.gov). A number of these have been completed: for some, the study results are reported in the literature (Table 3 ) and for others preliminary results have been reported, while others are still ongoing (Table 4).

The first of the Phase III studies reported was a randomized, double-blind, active- and placebo-controlled study investigating empagliflozin monotherapy in patients with type 2 diabetes [58]. Participants who had $\mathrm{HbA} 1 \mathrm{c}$ values of $7.0-10.0 \%$ at screening were randomized to once-daily empagliflozin $10 \mathrm{mg}$ or $25 \mathrm{mg}$, once-daily sitagliptin (100 mg), or placebo for 24 weeks. Screened patients with $\mathrm{HbA} 1 \mathrm{c}>10.0 \%$ were not excluded, but were assigned open-label empagliflozin $25 \mathrm{mg}$. After 24 weeks, placebo-adjusted mean differences in change from baseline were $-0.74 \%$ ( $95 \% \mathrm{Cl}:-0.88$ to -0.59 ; $p<0.0001$ ) for empagliflozin $10 \mathrm{mg},-0.85 \%$ (95\% Cl: -0.99 to $-0.71 ; p<0.0001)$ for empagliflozin $25 \mathrm{mg}$, and $-0.73 \%$ (95\% Cl: -0.88 to $-0.59 ; p<0.0001$ ) for sitagliptin. In the empagliflozin $25 \mathrm{mg}$ open-label arm, the mean $\mathrm{HbA} 1 \mathrm{c}$ fell from $11.5 \%$ at baseline to $7.6 \%$ at week 24 , with a mean change from baseline 
Table 3. Results in empagliflozin Phase III clinical trials.

\begin{tabular}{|c|c|c|c|}
\hline $\begin{array}{l}\text { Patients } \\
\text { Background therapy } \\
\text { Planned enrollment (n) }\end{array}$ & $\begin{array}{l}\text { Study } \\
\text { duration }\end{array}$ & Treatment arms & Primary endpoint \\
\hline Monotherapy & & & $\begin{array}{l}\text { Change from baseline in } \mathrm{HbA} 1 \mathrm{c} \text {, } \\
\text { mean }(95 \% \mathrm{Cl})\end{array}$ \\
\hline $\begin{array}{l}\text { NCT01177813 [58] } \\
\text { Adults with type } 2 \text { diabetes } \\
\text { Drug naïve } \\
\mathrm{n}=986\end{array}$ & 24 weeks & $\begin{array}{l}\text { Empagliflozin } 10 \mathrm{mg} \text { qd } \\
\text { Empagliflozin } 25 \mathrm{mg} \text { qd } \\
\text { Sitagliptin } 100 \mathrm{mg} \text { qd } \\
\text { Placebo } \\
\text { Open-label empagliflozin } 25 \text { mg qd }\end{array}$ & $\begin{array}{l}-0.66 \%(-0.76,-0.56) \\
-0.78 \%(-0.88,-0.67) \\
-0.66 \%(-0.76,-0.56) \\
+0.08 \%(-0.03,+0.18) \\
-3.70 \%(-4.11,-3.29)\end{array}$ \\
\hline Add-on therapy & & & $\begin{array}{l}\text { Change from baseline in } \mathrm{HbA} 1 \mathrm{c}, \\
\text { mean } \pm \mathrm{SE}\end{array}$ \\
\hline $\begin{array}{l}\text { NCT01210001 }[62] \\
\text { Adults with type } 2 \text { diabetes } \\
\text { Pioglitazone } \pm \text { metformin } \\
n=499\end{array}$ & 24 weeks & $\begin{array}{l}\text { Empagliflozin } 10 \mathrm{mg} \text { qd } \\
\text { Empagliflozin } 25 \mathrm{mg} \text { qd } \\
\text { Placebo }\end{array}$ & $\begin{array}{l}-0.59 \pm 0.07 \% \\
-0.72 \pm 0.07 \% \\
-0.11 \pm 0.07 \%\end{array}$ \\
\hline $\begin{array}{l}\text { NCT01159600-met }[60] \\
\text { Adults with type } 2 \text { diabetes } \\
\text { Metformin } \\
n=637\end{array}$ & 24 weeks & $\begin{array}{l}\text { Empagliflozin } 10 \text { mg qd } \\
\text { Empagliflozin } 25 \text { mg qd } \\
\text { Placebo } \\
\text { Open-label empagliflozin } 25 \text { mg qd }\end{array}$ & $\begin{array}{l}-0.70 \pm 0.05 \% \\
-0.77 \pm 0.05 \% \\
-0.13 \pm 0.05 \% \\
-3.23 \pm 0.22 \%\end{array}$ \\
\hline $\begin{array}{l}\text { NCT01159600 [61] } \\
\text { Adults with type } 2 \text { diabetes } \\
\text { Metformin + sulfonylurea } \\
\mathrm{n}=669\end{array}$ & 24 weeks & $\begin{array}{l}\text { Empagliflozin } 10 \text { mg qd } \\
\text { Empagliflozin } 25 \text { mg qd } \\
\text { Placebo } \\
\text { Open-label empagliflozin } 25 \text { mg qd }\end{array}$ & $\begin{array}{l}-0.82 \pm 0.05 \% \\
-0.77 \pm 0.05 \% \\
-0.17 \pm 0.05 \% \\
-2.89 \pm 0.16 \%\end{array}$ \\
\hline Special populations & & & $\begin{array}{l}\text { Co-primary endpoints: change from } \\
\text { baseline in } \mathrm{HbA1c} \text {, mean } \pm \mathrm{SE} \text { and } \\
\text { 24-hour SBP, mean } \pm \mathrm{SE}\end{array}$ \\
\hline \multirow[t]{2}{*}{$\begin{array}{l}\text { NCT01370005 [64] } \\
\text { Adults with type } 2 \text { diabetes } \\
\text { \& hypertension } \\
n=825\end{array}$} & 12 weeks & $\begin{array}{l}\text { Empagliflozin } 10 \mathrm{mg} \text { qd } \\
\text { Empagliflozin } 25 \mathrm{mg} \text { qd } \\
\text { Placebo }\end{array}$ & $\begin{array}{l}\text { HbA1c: }-0.59 \pm 0.04 \\
\text { 24-hour SBP: }-2.95 \pm 0.48 \\
\text { HbA1c: }-0.62 \pm 0.04 \\
24-\text { hour SBP: }-3.68 \pm 0.48 \\
\text { HbA1c: }+0.03 \pm 0.04 \\
\text { 24-hour SBP: }+0.48 \pm 0.49\end{array}$ \\
\hline & & & $\begin{array}{l}\text { Change from baseline in } \mathrm{HbA} 1 \mathrm{c} \text {, mean } \\
(95 \% \mathrm{Cl})\end{array}$ \\
\hline $\begin{array}{l}\text { NCT01164501 }[63] \\
\text { Adults with type } 2 \text { diabetes } \\
\text { \& renal impairment }{ }^{\mathrm{b}} \\
\text { Any antidiabetic therapy } \\
\mathrm{n}=741\end{array}$ & $\begin{array}{l}52 \text { weeks } \\
\text { (primary } \\
\text { endpoint } \\
\text { after } 24 \\
\text { weeks) }\end{array}$ & $\begin{array}{l}\text { Patients with stage } 2 \text { CKD: } \\
\text { Empagliflozin } 10 \text { mg qd } \\
\text { Empagliflozin } 25 \text { mg qd } \\
\text { Placebo } \\
\text { Patients with stage } 3 \text { CKD: } \\
\text { Empagliflozin } 25 \text { mg qd } \\
\text { Placebo }\end{array}$ & $\begin{array}{l}-0.46 \%(-0.60,-0.32) \\
-0.63 \%(-0.77,-0.49) \\
+0.06 \%(-0.08,+0.20) \\
-0.37(-0.47,-0.27) \\
+0.05(-0.05,+0.15)\end{array}$ \\
\hline
\end{tabular}

qd, once daily; SBP, systolic blood pressure.

an patients with screening $\mathrm{HbA} 1 \mathrm{c}>11 \%$.

${ }^{b}$ Estimated glomerular filtration rate (eGFR) of $<90 \mathrm{~mL} / \mathrm{min}$, as determined during screening and the run-in phase, using the Modification of Diet in Renal Disease (MDRD) equation, patients with eGFR $<15 \mathrm{~mL} / \mathrm{min}$ were excluded.

doi: 10.7573/dic.212262.t003

of $-3.7 \%(95 \% \mathrm{Cl}:-4.1$ to $-3.3 \%)$, and, among randomized patients with baseline $\mathrm{HbA} 1 \mathrm{c}<8.5 \%$, improvements in glycemic control were comparable between empagliflozin and sitagliptin groups; however, among patients with baseline $\mathrm{HbA} 1 \mathrm{c}>8.5 \%$, both empagliflozin doses elicited greater $\mathrm{HbA} 1 \mathrm{c}$ improvements when compared with sitagliptin. Adjusted mean changes from baseline in $\mathrm{HbA} 1 \mathrm{c}$ were $-1.04 \%$ (95\% Cl: -1.25 to -0.83 ) with sitagliptin compared with adjusted mean changes with empagliflozin $10 \mathrm{mg}$ of $-1.44 \%$ (95\% Cl: -1.64 to $-1.23 ; p=0.0077$ versus sitagliptin) and with empagliflozin 
Table 4. Empagliflozin Phase III clinical trials in progress.

\begin{tabular}{|c|c|c|c|}
\hline $\begin{array}{l}\text { Patients } \\
\text { Background therapy } \\
\text { Planned enrollment (n) }\end{array}$ & Study duration & Treatment arms & $\begin{array}{l}\text { Primary } \\
\text { endpoint } \\
\text { (planned) }\end{array}$ \\
\hline \multicolumn{4}{|l|}{ Add-on therapy } \\
\hline $\begin{array}{l}\text { NCT01167881 [67] } \\
\text { Adults with type } 2 \text { diabetes } \\
\text { Metformin } \\
\mathrm{n}=1549\end{array}$ & $\begin{array}{l}104 \text { weeks \& } \\
\text { 104-week } \\
\text { extension }\end{array}$ & $\begin{array}{l}\text { Empagliflozin } 25 \mathrm{mg} \text { qd } \\
\text { Glimepiride } 1-4 \mathrm{mg}\end{array}$ & $\mathrm{HbA1c}$ \\
\hline \multicolumn{4}{|l|}{ Combination regimens } \\
\hline $\begin{array}{l}\text { NCT01719003 } \\
\text { Adults with type } 2 \text { diabetes } \\
\text { Drug naïve } \\
\mathrm{n}=1364\end{array}$ & 24 weeks & $\begin{array}{l}\text { Empagliflozin } 10 \mathrm{mg} \text { qd } \\
\text { Empagliflozin } 25 \mathrm{mg} \text { qd } \\
\text { Empagliflozin } 10 \mathrm{mg} \text { divided dose + metformin } 500 \mathrm{mg} \text { bid } \\
\text { Empagliflozin } 10 \mathrm{mg} \text { divided dose + metformin } 1000 \mathrm{mg} \text { bid } \\
\text { Empagliflozin } 25 \mathrm{mg} \text { divided dose + metformin } 500 \mathrm{mg} \text { bid } \\
\text { Empagliflozin } 25 \mathrm{mg} \text { divided dose + metformin } 1000 \mathrm{mg} \text { bid } \\
\text { Metformin } 500 \mathrm{mg} \text { bid } \\
\text { Metformin } 1000 \mathrm{mg} \text { bid } \\
\text { Open-label empagliflozin } 25 \mathrm{mg} \text { divided doses + metformin } \\
1000 \mathrm{mg} \text { bid }\end{array}$ & HbA1c \\
\hline $\begin{array}{l}\text { NCT01734785 } \\
\text { Adults with type } 2 \text { diabetes } \\
\text { Drug naïve or metformin } \\
n=444\end{array}$ & 24 weeks & $\begin{array}{l}\text { Empagliflozin } 10 \text { mg + linagliptin } 5 \text { mg FDC qd } \\
\text { Empagliflozin } 25 \text { mg + linagliptin } 5 \text { mg FDC qd } \\
\text { Linagliptin } 5 \text { mg qd }\end{array}$ & HbA1c \\
\hline $\begin{array}{l}\text { NCT01422876 } \\
\text { Adults with type } 2 \text { diabetes } \\
\text { Drug naïve or metformin } \\
n=1406\end{array}$ & 52 weeks & $\begin{array}{l}\text { Empagliflozin } 25 \mathrm{mg}+\text { linagliptin } 5 \mathrm{mg} \text { FDC qd } \\
\text { Empagliflozin } 10 \mathrm{mg}+\text { linagliptin } 5 \mathrm{mg} \text { FDC qd } \\
\text { Empagliflozin } 25 \mathrm{mg} \text { qd } \\
\text { Empagliflozin } 10 \mathrm{mg} \text { qd } \\
\text { Linagliptin } 5 \mathrm{mg} \text { qd }\end{array}$ & HbA1c \\
\hline $\begin{array}{l}\text { NCT01778049 } \\
\text { Adults with type } 2 \text { diabetes } \\
\text { Metformin } \\
\mathrm{n}=690\end{array}$ & 24 weeks & $\begin{array}{l}\text { Empagliflozin } 10 \mathrm{mg} \text { + linagliptin } 5 \mathrm{mg} \text { FDC qd } \\
\text { Empagliflozin } 25 \mathrm{mg} \text { + linagliptin } 5 \mathrm{mg} \text { FDC qd } \\
\text { Empagliflozin } 10 \mathrm{mg} \text { + placebo FDC qd } \\
\text { Empagliflozin } 25 \mathrm{mg} \text { + placebo FDC qd }\end{array}$ & HbA1c \\
\hline \multicolumn{4}{|l|}{ Special populations } \\
\hline $\begin{array}{l}\text { NCT01306214 } \\
\text { Adults with type } 2 \text { diabetes } \\
\text { \& obesity } \\
\text { Insulin } \pm \text { metformin } \\
n=566\end{array}$ & $\begin{array}{l}52 \text { weeks } \\
\text { (primary } \\
\text { endpoint after } \\
18 \text { weeks) }\end{array}$ & $\begin{array}{l}\text { Empagliflozin } 10 \mathrm{mg} \text { qd } \\
\text { Empagliflozin } 25 \mathrm{mg} \text { qd } \\
\text { Placebo }\end{array}$ & HbA1c \\
\hline \multicolumn{4}{|l|}{ Ethnic/Racial groups } \\
\hline $\begin{array}{l}\text { NCT01947855 } \\
\text { Japanese adults with type } 2 \\
\text { diabetes } \\
\text { Drug naïve or } 1 \text { OAD } \\
n=60\end{array}$ & 4 weeks & $\begin{array}{l}\text { Empagliflozin } 10 \mathrm{mg} \text { qd } \\
\text { Empagliflozin } 25 \mathrm{mg} \text { qd } \\
\text { Placebo }\end{array}$ & PPG \\
\hline $\begin{array}{l}\text { NCT01368081 } \\
\text { Japanese adults with type } 2 \\
\text { diabetes } \\
1 \text { OAD } \\
n=1162\end{array}$ & 52 weeks & $\begin{array}{l}\text { Empagliflozin } 10 \mathrm{mg} \text { qd } \\
\text { Empagliflozin } 25 \mathrm{mg} \text { qd } \\
\text { Metformin }\end{array}$ & Safety \\
\hline
\end{tabular}




\begin{tabular}{|c|c|c|c|}
\hline $\begin{array}{l}\text { Patients } \\
\text { Background therapy } \\
\text { Planned enrollment (n) }\end{array}$ & Study duration & Treatment arms & $\begin{array}{l}\text { Primary } \\
\text { endpoint } \\
\text { (planned) }\end{array}$ \\
\hline \multicolumn{4}{|l|}{ Long-term safety } \\
\hline $\begin{array}{l}\text { NCT01289990 } \\
\text { Extension of } \\
\text { NCT01210001, NCT01177813, } \\
\text { or NCT01159600 } \\
n=1869\end{array}$ & $\begin{array}{l}76 \text { weeks total } \\
\text { (52-week } \\
\text { extension } \\
\text { to } 24 \text {-week } \\
\text { trials) }\end{array}$ & $\begin{array}{l}\text { Patients continue previous treatment as randomized in } \\
24 \text {-week trials }\end{array}$ & Safety \\
\hline $\begin{array}{l}\text { NCT01131676 [68] } \\
\text { Adults with type } 2 \text { diabetes } \\
\text { \& increased cardiovascular } \\
\text { risk (EMPA-REG OUTCOMETM) } \\
n=7000\end{array}$ & $\begin{array}{l}\text { Endpoint driven } \\
\text { - expected } \sim 5 \\
\text { years }\end{array}$ & $\begin{array}{l}\text { Empagliflozin } 10 \text { mg qd } \\
\text { Empagliflozin } 25 \mathrm{mg} \text { qd } \\
\text { Placebo (usual care) }\end{array}$ & $\begin{array}{l}\text { CV death, } \\
\text { non-fatal } \\
\text { MI, or } \\
\text { non-fatal } \\
\text { stroke }^{\text {a }}\end{array}$ \\
\hline \multicolumn{4}{|c|}{$\begin{array}{l}\text { bid, twice daily; CV, cardiovascular; FDC, fixed-dose combination; MI, myocardial infarction, OAD, oral antidiabetes drug; } \\
\text { PPG, post-prandial glucose; qd, once daily. } \\
\text { aFirst occurrence of any of the following adjudicated components of the primary composite endpoint: CV death (including } \\
\text { fatal stroke and fatal MI), non-fatal MI and non-fatal stroke. } \\
\text { Based on a search of the US National Institutes of Health clinical trial registry, for trials of empagliflozin and Phase III } \\
\text { (including completed, ongoing and planned studies) conducted October 17, 2013; studies with published results were not } \\
\text { included. } \\
\text { doi: } 10.7573 / \text { dic. } 212262 . t 004\end{array}$} \\
\hline
\end{tabular}

$25 \mathrm{mg}$ of $-1.43 \%$ (95\% Cl: -1.65 to $-1.21 ; p=0.0119$ versus sitagliptin). Empagliflozin also mediated clinically relevant reductions in weight, waist circumference, and blood pressure compared with either placebo or sitagliptin. Furthermore, both empagliflozin doses were well tolerated with no increased risk of hypoglycemia versus placebo or sitagliptin. Adverse events consistent with urinary tract infection occurred at similar rates across the groups, but when analyzed separately, were reported more frequently in female patients treated with empagliflozin compared with those treated with placebo or sitagliptin. Events consistent with genital infection were more frequently reported with empagliflozin, although all events were considered mild.

One of the key hypothetical advantages of SGLT2 inhibitors such as empagliflozin is the ability to use them in combination with any of the current treatment options for glycemic control, since the mechanism of action is independent of insulin and should complement all other currently available agents [59]. To investigate this, additional Phase III trials have investigated empagliflozin as an add-on therapy to other glucose-lowering treatments for 24 weeks. Empagliflozin as add-on to metformin improved glycemic control, as well as inducing significant reductions in body weight and blood pressure [60]. At 24 weeks, $\mathrm{HbA} 1 \mathrm{c}$ was improved by a placebo-corrected mean of $-0.57 \%$ (95\% Cl: $-0.70,-0.43)$ with empagliflozin $10 \mathrm{mg}$ and $-0.64 \%$ (95\% Cl: $-0.77,-0.50$ ) with empagliflozin 25 mg; both $p<0.001$ vs placebo. This combination of agents was also well tolerated, with a low risk of hypoglycemia [60]. When empagliflozin was investigated as an add-on therapy to metformin and sulfonylurea, and to pioglitazone with or without metformin, similar results in terms of improvements in glycemic control, body weight, and blood pressure were demonstrated (Table 3) [61,62]. Empagliflozin was also well tolerated in these studies, although there was a higher incidence of hypoglycemia with empagliflozin in combination with metformin and sulfonylurea [61,62].

Results have also been reported for studies in patients with type 2 diabetes and renal impairment [63], and for patients with hypertension [64]. In the study of patients with type 2 diabetes and renal impairment, patients with CKD stage 2 (that is, mild renal impairment with eGFR $\geq 60$ to $<90 \mathrm{~mL} / \mathrm{min} / 1.73 \mathrm{~m}^{2}$ ) or CKD stage 3 (moderate renal impairment with eGFR $\geq 30$ to $<60 \mathrm{~mL} / \mathrm{min} / 1.73 \mathrm{~m}^{2}$ ) were randomized to empagliflozin or placebo as add-on to existing therapy for 52 weeks [63]. By design, patients with mild renal impairment could receive empagliflozin $10 \mathrm{mg}$ or $25 \mathrm{mg}$, while those with moderate renal impairment received $25 \mathrm{mg}$. Empagliflozin was well tolerated in these patients; small decreases in eGFR were observed, which reversed within 3 weeks after the end of treatment, indicating this effect is due to hemodynamic changes associated with SGLT2 inhibition [63]. The primary efficacy endpoint was the change to week 24 and, compared with placebo, empagliflozin significantly reduced $\mathrm{HbA} 1 \mathrm{C}$ in both groups. In the group with stage 2 CKD, the adjusted mean changes from baseline in $\mathrm{HbA} 1 \mathrm{c}$ versus placebo at week 24 were $-0.52 \%$ (95\% Cl: -0.72 to -0.32 ) for empagliflozin $10 \mathrm{mg}$ and $-0.68 \%(95 \% \mathrm{Cl}:-0.88$ to -0.49 ) for empagliflozin $25 \mathrm{mg}$ (both $p<0.0001$ ), while in patients with stage $3 \mathrm{CKD}$, it was $-0.42 \%(95 \% \mathrm{Cl}:-0.56$ to -0.28) for empagliflozin $25 \mathrm{mg}(p<0.0001)$; these reductions were sustained to 52 weeks. Both groups of patients also had 
improvement in FPG, body weight, and blood pressure at week 24. While attenuated efficacy of SGLT2 inhibitors is expected in patients with renal impairment, these results suggest patients with mild or moderate renal impairment could achieve clinically significant improvements with empagliflozin, as has also been seen with canagliflozin [65]. However, conflicting results have been seen with dapagliflozin, where reductions in $\mathrm{HbA} 1 \mathrm{c}$ did not meet statistical significance in patients with moderate renal impairment (eGFR 30-59 mL/min/1.73 $\mathrm{m}^{2}$ ) [66].

In the second study, patients with type 2 diabetes and hypertension (mean seated systolic blood pressure 130-159 $\mathrm{mmHg}$ and diastolic blood pressure $80-99 \mathrm{mmHg}$ ) were randomized to empagliflozin $10 \mathrm{mg}, 25 \mathrm{mg}$, or placebo for 12 weeks [64]. Preliminary results have been reported, and both empagliflozin doses were associated with significant improvements in $\mathrm{HbA} 1 \mathrm{c}$ and systolic blood pressure after 12 weeks, with $18 \%$ of the empagliflozin 25 -mg group and $16 \%$ of the 10-mg group meeting blood pressure control targets, versus $8 \%$ of the placebo group [64].

Other Phase III trials of empagliflozin are still in the planned stages or ongoing, but include fixed-dose combination regimens, and trials in Japanese patients. A head-to-head trial comparing empagliflozin $25 \mathrm{mg}$ with glimepiride 1-4 mg, both as add-on to background metformin, is also under way and should provide valuable information for the common clinical decision of the optimal second-line therapy to add to metformin [67]. An ongoing multicenter, randomized, doubleblind, placebo-controlled cardiovascular outcome event trial (EMPA-REG OUTCOMETM, registered as NCT01131676) with empagliflozin was designed to assess the effect of empagliflozin (10 mg or $25 \mathrm{mg}$ ) compared with usual care on cardiovascular events. The investigators plan to recruit more than 7000 patients with type 2 diabetes with an elevated cardiovascular risk and the trial is designed to test firstly for cardiovascular safety. If safety is demonstrated in this cardiovascular outcomes study, the trial is powered to test for a reduced risk of cardiovascular events (that is, superiority) with empagliflozin [68]. In addition to the clinical trial program, post-marketing safety assessments will be an essential part of confirming long-term safety in clinical practice, and such studies have been required for the previously approved SGLT2 inhibitors, canagliflozin and dapagliflozin $[69,70]$. For empagliflozin, information is not yet available, but assuming they are undertaken, post-marketing pharmacovigilance studies with empagliflozin could not only assess long-term safety but would additionally be useful in assessing the risk of potential adverse events noted with other agents within this therapeutic class.

\section{Beyond type 2 diabetes?}

Due to the mechanism of action of SGLT2 inhibitors, they have pharmacologic consequences in addition to glucose lowering that could translate into beneficial effects in patients with type 2 diabetes [13]. The increased UGE leads not only to reduced blood sugar and to weight loss, but potentially also to reductions in blood pressure, which at least in part could be mediated via osmotic diuresis [13]. While these agents may lend themselves to treatment in patients with hypertension or obesity, as yet, no trials have been registered for empagliflozin as a treatment for either condition, in patients without type 2 diabetes.

However, SGLT2 inhibitors are unique among oral antidiabetes drugs in that they are not dependent on endogenous insulin, making treatment of patients with type 1 diabetes a possibility [19]; and there have been some early trials in this area. In streptozotocin-induced rat models of type 1 diabetes, empagliflozin in combination with $1.5 \mathrm{IU}$ insulin induced a similar glucose-lowering effect to 6 IU insulin, suggesting empagliflozin could be a useful option to allow dose reduction of insulin [71]. A pilot study in patients with type 1 diabetes enrolled 42 patients in an 8-week, single-arm, open-label, Phase II study of empagliflozin $25 \mathrm{mg}$ once daily as adjunctive therapy to insulin [72]. In this short-term study, empagliflozin was associated with improvement in glycemic control, a reduction in rates of hypoglycemia, a substantial reduction in insulin requirement and body weight, and was generally well tolerated, suggesting it may have potential in these patients. However, as the primary endpoint of the study, the investigators assessed glomerular filtration rate and effective renal plasma flow under clamped euglycemic conditions (4-6 mmol/L) and hyperglycemic conditions (9-11 $\mathrm{mmol} / \mathrm{L})$ at baseline and again after 8 weeks of empagliflozin treatment, and compared results for patients with hyperfiltration (GFR $\geq 135 \mathrm{~mL} / \mathrm{min} / 1.73 \mathrm{~m}^{2}, \mathrm{n}=27$ ) or normal GFR ( $n=13)$ [73]. In the patients with hyperfiltration, empagliflozin attenuated hyperfiltration under euglycemic and hyperglycemic conditions. This was accompanied by declines in plasma nitric oxide levels and effective renal plasma flow and an increase in renal vascular resistance. In the patients with normal GFR, empagliflozin did not affect GFR, other renal function parameters, or plasma nitric oxide levels [73]. These results support further evaluation of empagliflozin in type 1 diabetes, with a potential role in reducing the risk of diabetic nephropathy via reducing renal hyperfiltration.

\section{Potential role of empagliflozin in the treatment of diabetes}

The clinical development of SGLT2 inhibitors represents an interesting and important addition to the range of treatments currently available to manage hyperglycemia. Of note, these oral agents provide an insulin-independent mechanism to reduce hyperglycemia through inhibition of SGLT2 and excretion of excess glucose by the urine. Pharmacokinetic studies of empagliflozin have shown that it is rapidly absorbed following oral administration, reaching maximal plasma concentrations within 1-3 hours. Early studies also have demonstrated that once-daily administration of empagliflozin in patients with type 2 diabetes is well tolerated 
and results in improved glycemic control, with a lack of drugdrug interactions seen when taken with other commonly administered medications. Phase II and III trials have also shown that empagliflozin, as monotherapy or add-on to other glucoselowering treatments, led to improved glycemic control, with the largest reductions seen in those with the highest $\mathrm{HbA} 1 \mathrm{c}$ levels at baseline. Empagliflozin was generally well tolerated, with few patients discontinuing therapy due to AEs, despite an increased incidence of genital infections. Importantly, there was no increased risk of hypoglycemia versus placebo, which could be a key consideration for many patients, as could the reductions in body weight and blood pressure, suggesting empagliflozin could be a useful option in many patients.

In the USA, empagliflozin may well be approved for glycemic control in patients with type 2 diabetes, both as monotherapy and in combination with other agents, as was the case for canagliflozin and dapagliflozin $[74,75]$. Since the drug class is so newly available, expert groups will likely recommend use with caution initially [76], and data from the overall empagliflozin clinical trial program will need to be collated to determine if the drug has any specific properties that may distinguish its use over other members of the SGLT2 class. However, when further experience is gained, this drug class has the potential to be widely used since it offers the obvious advantages of oral dosing with a mechanism of action complementary to currently available therapies.

Initially, it may be expected that empagliflozin will be used as an add-on therapy to metformin, the most widely recommended first-line therapy [77]. Most patients who cannot be considered for metformin because of renal impairment would also not be suitable for empagliflozin treatment, since SGLT2 inhibitors have limited efficacy in patients with severe renal impairment [76]. For patients unable to tolerate metformin due to gastrointestinal effects, SGLT2 inhibitors are among the alternative monotherapies that provide improvements in $\mathrm{HbA} 1 \mathrm{c}$ levels without weight gain or increased hypoglycemia risk (along with glucagon-like peptide 1 [GLP-1] receptor agonists, dipeptidyl-peptidase-4 [DPP-4] inhibitors, and alpha-glucosidase inhibitors) [76].

For patients on metformin for whom additional glucose control is needed, empagliflozin may prove a particularly useful option for those unwilling to begin parenteral therapy, especially for those who need to avoid weight gain. The weight loss observed in clinical trials can be appreciable, and may offset the weight gain typically associated with other agents such as insulin secretagogues and thiazolidinediones. The lack of hypoglycemia is also of interest, making empagliflozin an appealing option for those who have difficult-to-manage hypoglycemic episodes, or who need to make particular effort to avoid hypoglycemia.

In the clinical development program, empagliflozin is being tested in combination with a variety of other agents in addition to metformin, including sulfonylureas, insulin, thiazolidinediones, and DPP-4 inhibitors. The insulin-independent mechanism of action of empagliflozin suggests it will complement these options, and this appears to be borne out by the results reported to date. Therefore, we may expect that empagliflozin will also be used as a component of triple combination regimens with many of these agents, as recommended for patients not achieving therapeutic targets on dual therapy [36]. In clinical trials, patients whose blood glucose was not controlled on dual therapy were significantly more likely to achieve goal with addition of empagliflozin; however, where very large reductions in $\mathrm{HbA} 1 \mathrm{c}$ are still required despite dual therapy, it may be more appropriate to consider insulin. For patients on insulin, addition of empagliflozin may be considered as an adjunctive agent, not only because of the expected improvements in $\mathrm{HbA} 1 \mathrm{c}$ and weight, but also as a potential alternative to up-titration of insulin, and clinical trials have shown patients can even achieve significant reductions in their insulin doses with long-term empagliflozin add-on to insulin.

The number of agents on the market allow combination therapy to be individualized to each patient's needs, although the combination of metformin, a DPP-4 inhibitor and an SGLT2 inhibitor is especially appealing, since it would not be expected to result in weight gain or hypoglycemia. It is too early to determine whether animal studies suggesting preservation of islet function/mass and improved insulin action will translate into clinical effects, although these suggest that empagliflozin should have sustained benefit over the long term, and may also have a role in early treatment of recently diagnosed patients.

\section{Contributions}

The author was fully responsible for all content and editorial decisions, was involved at all stages of manuscript development, and has approved the final version of the review that reflects the author's interpretation and conclusions.

\section{Potential conflicts of interest}

The International Committee of Medical Journal Editors' (ICMJE) Potential Conflicts of Interests form for the author is summarized below. The original form is available for download at: http://www.drugsincontext.com/wp-content/ uploads/2014/07/dic.212262-COI.pdf

$\mathrm{JN}$ reports receiving consultancy/speakers bureau fees from Janssen Pharmaceuticals and Sanofi. His institution has received grant support from Amylin, Johnson \& Johnson, Merck, AstraZeneca, and Novo Nordisk.

\section{Acknowledgements}

Medical writing assistance, supported financially by Boehringer Ingelheim, was provided by Geraldine Thompson of Envision Scientific Solutions during the preparation of this review. Boehringer Ingelheim was given the opportunity to check the data used in the manuscript for factual accuracy only. 


\section{References}

1. Zoungas S, Chalmers J, Ninomiya T et al. Association of $\mathrm{HbA} 1 \mathrm{c}$ levels with vascular complications and death in patients with type 2 diabetes: evidence of glycaemic thresholds. Diabetologia 2012;55:636-43. http://dx.doi.org/10.1007/s00125-011-2404-1

2. Lachin JM, Orchard TJ, Nathan DM. Update on cardiovascular outcomes at 30 years of the diabetes control and complications trial/epidemiology of diabetes interventions and complications study. Diabetes Care 2014;37:39-43. http://dx.doi.org/10.2337/dc13-2116

3. UK Prospective Diabetes Study (UKPDS) Group. Intensive blood-glucose control with sulphonylureas or insulin compared with conventional treatment and risk of complications in patients with type 2 diabetes (UKPDS 33). Lancet 1998;352:837-53.

4. Holman RR, Paul SK, Bethel MA, Matthews DR, Neil HA. 10-year follow-up of intensive glucose control in type 2 diabetes. N Engl J Med 2008;359:1577-89. http://dx.doi.org/10.1056/NEJMoa0806470

5. Ali MK, Bullard KM, Saaddine JB, Cowie CC, Imperatore G, Gregg EW. Achievement of goals in U.S. diabetes care, 19992010. N Engl J Med 2013;368:1613-24.

http://dx.doi.org/10.1056/NEJMsa1213829

6. Mitchell BD, Vietri J, Zagar A, Curtis B, Reaney M. Hypoglycaemic events in patients with type 2 diabetes in the United Kingdom: associations with patient-reported outcomes and self-reported HbA1c. BMC Endocr Disord 2013;13:59.

http://dx.doi.org/10.1186/1472-6823-13-59

7. Aronson R. The role of comfort and discomfort in insulin therapy. Diabetes Technol Ther 2012;14:741-7. http://dx.doi.org/10.1089/dia.2012.0038

8. Turner RC, Cull CA, Frighi V, Holman RR. Glycemic control with diet, sulfonylurea, metformin, or insulin in patients with type 2 diabetes mellitus: progressive requirement for multiple therapies (UKPDS 49). UK Prospective Diabetes Study (UKPDS) Group. JAMA 1999;281:2005-12. http://dx.doi.org/10.1001/jama.281.21.2005

9. Bays H. Sodium glucose co-transporter type 2 (SGLT2) inhibitors: targeting the kidney to improve glycemic control in diabetes mellitus. Diabetes Ther 2013;4:195-220. http://dx.doi.org/10.1007/s13300-013-0042-y

10. Gerich JE. Role of the kidney in normal glucose homeostasis and in the hyperglycaemia of diabetes mellitus: therapeutic implications. Diabet Med 2010;27:136-42. http://dx.doi.org/10.1111/j.1464-5491.2009.02894.x

11. Mather A, Pollock C. Glucose handling by the kidney. Kidney Int Suppl 2011:S1-S6. http://dx.doi.org/10.1038/ki.2010.509

12. Abdul-Ghani MA, Defronzo RA, Norton L. Novel hypothesis to explain why SGLT2 inhibitors inhibit only $30-50 \%$ of filtered glucose load in humans. Diabetes 2013;62:3324-8. http://dx.doi.org/10.2337/db13-0604
13. Tahrani AA, Barnett AH, Bailey CJ. SGLT inhibitors in management of diabetes. Lancet Diabetes Endocrinol 2013;1:140-51. http://dx.doi.org/10.1016/S2213-8587(13)70050-0

14. Kanai Y, Lee WS, You G, Brown D, Hediger MA. The human kidney low affinity Na+/glucose cotransporter SGLT2. Delineation of the major renal reabsorptive mechanism for D-glucose. J Clin Invest 1994;93:397-404. http://dx.doi.org/10.1172/JCI116972

15. Vallon V, Platt KA, Cunard R et al. SGLT2 mediates glucose reabsorption in the early proximal tubule. J Am Soc Nephrol 2011;22:104-12. http://dx.doi.org/10.1681/ASN.2010030246

16. Wright EM. Renal $\mathrm{Na}(+)$-glucose cotransporters. Am J Physiol Renal Physiol 2001;280:F10-8.

17. You G, Lee WS, Barros EJ et al. Molecular characteristics of $\mathrm{Na}(+)$-coupled glucose transporters in adult and embryonic rat kidney. J Biol Chem 1995;270:29365-71.

18. Chen J, Williams S, Ho S et al. Quantitative PCR tissue expression profiling of the human SGLT2 gene and related family members. Diabetes Ther 2010;1:57-92. http://dx.doi.org/10.1007/s13300-010-0006-4

19. DeFronzo RA, Davidson JA, Del Prato S. The role of the kidneys in glucose homeostasis: a new path towards normalizing glycaemia. Diabetes Obes Metab 2012;14:5-14. http://dx.doi.org/10.1111/j.1463-1326.2011.01511.x

20. Rahmoune H, Thompson PW, Ward JM, Smith CD, Hong $\mathrm{G}$, Brown J. Glucose transporters in human renal proximal tubular cells isolated from the urine of patients with noninsulin-dependent diabetes. Diabetes 2005;54:3427-34. http://dx.doi.org/10.2337/diabetes.54.12.3427

21. Marsenic O. Glucose control by the kidney: an emerging target in diabetes. Am J Kidney Dis 2009;53:875-83. http://dx.doi.org/10.1053/j.ajkd.2008.12.031

22. Martin MG, Turk E, Lostao MP, Kerner C, Wright EM. Defects in $\mathrm{Na}+$ /glucose cotransporter (SGLT1) trafficking and function cause glucose-galactose malabsorption. Nat Genet 1996;12:216-20. http://dx.doi.org/10.1038/ng0296-216

23. Santer R, Calado J. Familial renal glucosuria and SGLT2: from a mendelian trait to a therapeutic target. Clin J Am Soc Nephrol 2010;5:133-41. http://dx.doi.org/10.2215/CJN.04010609

24. Abdul-Ghani MA, Norton L, Defronzo RA. Role of sodiumglucose cotransporter 2 (SGLT 2) inhibitors in the treatment of type 2 diabetes. Endocr Rev 2011;32:515-31. http://dx.doi.org/10.1210/er.2010-0029

25. Chan HW, Ashan B, Jayasekera P, Collier A, Ghosh S. A new class of drug for the management of type 2 diabetes: sodium glucose co-transporter inhibitors: 'glucuretics'. Diabetes Metab Syndr 2012;6:224-8. http://dx.doi.org/10.1016/j.dsx.2012.08.003

26. Ehrenkranz JR, Lewis NG, Kahn CR, Roth J. Phlorizin: a review. Diabetes Metab Res Rev 2005;21:31-8. http://dx.doi.org/10.1002/dmrr.532 
27. Washburn WN, Poucher SM. Differentiating sodiumglucose co-transporter-2 inhibitors in development for the treatment of type 2 diabetes mellitus. Expert Opin Investig Drugs 2013;22:463-86. http://dx.doi.org/10.1517/13543784.2013.774372

28. United States Adopted Names Council (USANC) and American Medical Association. Statement on a nonproprietary name adopted by the USAN council: USAN (ZZ-108) empagliflozin, 2012. www.ama-assn.org/ resources/doc/usan/empagliflozin.pdf (Last accessed January 21 2014).

29. Grempler R, Thomas L, Eckhardt M et al. Empagliflozin, a novel selective sodium glucose cotransporter-2 (SGLT-2) inhibitor: characterisation and comparison with other SGLT2 inhibitors. Diabetes Obes Metab 2012;14:83-90. http://dx.doi.org/10.1111/j.1463-1326.2011.01517.x

30. Polidori D, Sha S, Mudaliar S et al. Canagliflozin lowers postprandial glucose and insulin by delaying intestinal glucose absorption in addition to increasing urinary glucose excretion: results of a randomized, placebocontrolled study. Diabetes Care 2013;36:2154-61. http://dx.doi.org/10.2337/dc12-2391

31. Thomas L, Grempler R, Eckhardt M et al. Long-term treatment with empagliflozin, a novel, potent and selective SGLT-2 inhibitor, improves glycaemic control and features of metabolic syndrome in diabetic rats. Diabetes Obes Metab 2012;14:94-6. http://dx.doi.org/10.1111/j.1463-1326.2011.01518.x

32. Jelsing J, Vrang N, Mark M, Mayoux E, Klein T. The sodium glucose cotransporter-2 (SGLT-2) inhibitor empagliflozin has a durable effect on the restoration of glucose homeostasis by preserving beta-cell mass in Zucker diabetic fatty rats. Abstract 1018-P presented at the 72nd Annual Scientific Sessions of the American Diabetes Association, Philadelphia, PA, USA. Diabetes 2012;61:A261.

33. Grempler R, Thomas $L$, Klein $T$ et al. Weight loss induced by the potent and selective SGLT2 inhibitor, BI 10773, is due to body fat reduction. Studies in dietary-induced obese rats. Abstract 1793-P presented at the 70th Scientific Sessions of the American Diabetes Association, Orlando, FL, USA. Diabetes 2010;59:469.

34. Seman L, Macha S, Nehmiz G et al. Empagliflozin (BI 10773), a potent and selective SGLT2 inhibitor, induces dosedependent glucosuria in healthy subjects. Clin Pharmacol Drug Dev 2013;2:152-61. http://dx.doi.org/10.1002/cpdd.16

35. Sarashina A, Koiwai K, Seman LJ et al. Safety, tolerability, pharmacokinetics and pharmacodynamics of single doses of empagliflozin, a sodium glucose cotransporter 2 (SGLT2) inhibitor, in healthy Japanese subjects. Drug Metab Pharmacokinet 2013;28:213-9. http://dx.doi.org/10.2133/dmpk.DMPK-12-RG-082

36. American Diabetes Association. Standards of medical care in diabetes--2014. Diabetes Care 2014;37 Suppl 1:S14-80. http://dx.doi.org/10.2337/dc14-S014
37. Macha S, Dieterich S, Mattheus M, Seman LJ, Broedl UC, Woerle HJ. Pharmacokinetics of empagliflozin, a sodium glucose cotransporter-2 (SGLT2) inhibitor, and metformin following co-administration in healthy volunteers. Int J Clin Pharmacol Ther 2013;51:132-40. http://dx.doi.org/10.5414/CP201794

38. Brand T, Macha S, Mattheus M, Pinnetti S, Woerle HJ. Pharmacokinetics of empagliflozin, a sodium glucose cotransporter-2 (SGLT-2) inhibitor, coadministered with sitagliptin in healthy volunteers. Adv Ther 2012;29:889-99. http://dx.doi.org/10.1007/s12325-012-0055-3

39. Friedrich C, Metzmann K, Rose P, Mattheus M, Pinnetti S, Woerle HJ. A randomized, open-label, crossover study to evaluate the pharmacokinetics of empagliflozin and linagliptin after coadministration in healthy male volunteers. Clin Ther 2013;35:A33-A42. http://dx.doi.org/10.1016/j.clinthera.2012.12.002

40. Macha S, Mattheus M, Pinnetti S, Seman L, Woerle HJ. Pharmacokinetics of empagliflozin, a sodium glucose cotransporter 2 inhibitor, and glimepiride following co-administration in healthy volunteers: A randomised, open-label, crossover Study. J Diab Res Clin Met 2012; 1:1-7. http://dx.doi.org/10.7243/2050-0866-1-14

41. Macha S, Rose P, Mattheus M, Pinnetti S, Woerle HJ. Lack of drug-drug interaction between empagliflozin, a sodium glucose cotransporter 2 inhibitor, and warfarin in healthy volunteers. Diabetes Obes Metab 2013;15:316-23. http://dx.doi.org/10.1111/dom.12028

42. Giessmann T, Heise T, Macha S et al. Lack of interaction between the sodium glucose co-transporter 2 inhibitor empagliflozin and hydrochlorothiazide or torasemide in patients with T2DM. Abstract 2440-PO presented at the 72nd Annual Scientific Sessions of the American Diabetes Association, Pennsylvania, PA, USA. Diabetes 2012;61:A614.

43. Macha S, Sennewald R, Rose P et al. Lack of clinically relevant drug-drug interaction between empagliflozin, a sodium glucose cotransporter 2 inhibitor, and verapamil, ramipril, or digoxin in healthy volunteers. Clin Ther 2013;35:226-35. http://dx.doi.org/10.1016/j.clinthera.2013.02.015

44. Macha S, Lang B, Pinnetti S et al. Lack of pharmacokinetic interaction between the sodium glucose cotransporter-2 (SGLT-2) inhibitor empagliflozin and simvastatin in healthy volunteers. Abstract PCS-33-7 presented at the American College of Clinical Pharmacology Annual Meeting, September 23-25, San Diego, CA, USA. Clinical Pharmacology in Drug Development 2012; 1:181.

45. Macha S, Mattheus M, Pinnetti S, Woerle HJ, Broedl UC. Effect of empagliflozin on the steady-state pharmacokinetics of ethinylestradiol and levonorgestrel in healthy female volunteers. Clin Drug Investig 2013;33: 351-7. http://dx.doi.org/10.1007/s40261-013-0068-y

46. Ring A, Brand T, Macha $S$ et al. The sodium glucose cotransporter 2 inhibitor empagliflozin does not prolong 
QT interval in a thorough QT (TQT) study. Cardiovasc Diabetol 2013;12:70. http://dx.doi.org/10.1186/1475-2840-12-70

47. Heise T, Seman L, Macha S et al. Safety, tolerability, pharmacokinetics, and pharmacodynamics of multiple rising doses of empagliflozin in patients with type 2 diabetes mellitus. Diabetes Ther 2013;4:331-45. http://dx.doi.org/10.1007/s13300-013-0030-2

48. Heise T, Seewaldt-Becker E, Macha S et al. Safety, tolerability, pharmacokinetics and pharmacodynamics following 4 weeks' treatment with empagliflozin once daily in patients with type 2 diabetes. Diabetes Obes Metab 2013;15:613-21. http://dx.doi.org/10.1111/dom.12073

49. Kanada S, Koiwai K, Taniguchi A, Sarashina A, Seman L, Woerle HJ. Pharmacokinetics, pharmacodynamics, safety and tolerability of 4 weeks' treatment with empagliflozin in Japanese patients with type 2 diabetes mellitus. J Diabetes Investig 2013;4:613-7. http://dx.doi.org/10.1111/jdi.12110

50. Macha S, Mattheus M, Halabi A, Pinnetti S, Woerle HJ, Broedl UC. Pharmacokinetics, pharmacodynamics and safety of empagliflozin, a sodium glucose cotransporter 2 (SGLT2) inhibitor, in subjects with renal impairment. Diabetes Obes Metab 2014;16:215-22. http://dx.doi.org/10.1111/dom.12182

51. Macha S, Rose P, Mattheus M et al. Pharmacokinetics, safety and tolerability of empagliflozin, a sodium glucose cotransporter 2 inhibitor, in patients with hepatic impairment. Diabetes Obes Metab 2014;16:118-23. http://dx.doi.org/10.1111/dom.12183

52. Ferrannini E, Seman L, Seewaldt-Becker E, Hantel S, Pinnetti S, Woerle HJ. A Phase Ilb, randomized, placebo-controlled study of the SGLT2 inhibitor empagliflozin in patients with type 2 diabetes. Diabetes Obes Metab 2013;15:721-8. http://dx.doi.org/10.1111/dom.12081

53. Rosenstock J, Seman LJ, Jelaska A et al. Efficacy and safety of empagliflozin, a sodium glucose cotransporter 2 (SGLT2) inhibitor, as add-on to metformin in type 2 diabetes with mild hyperglycaemia. Diabetes Obes Metab 2013;15: 1154-60. http://dx.doi.org/10.1111/dom.12185

54. Hach T, Lambers Heerspink HJ, Pfarr E et al. The sodium glucose cotransporter-2 (SGLT-2) inhibitor empagliflozin lowers blood pressure independent of weight or $\mathrm{HbA} 1 \mathrm{c}$ changes. Abstract presented at the 48th Annual Meeting of the European Association for the Study of Diabetes, October 1-5, Berlin, Germany. Diabetologia 2012;55:S317.

55. Ferrannini E, Berk A, Hantel S et al. Long-term safety and efficacy of empagliflozin, sitagliptin, and metformin: an active-controlled, parallel-group, randomized, 78-week open-label extension study in patients with type 2 diabetes. Diabetes Care 2013;36:4015-21. http://dx.doi.org/10.2337/dc13-0663

56. Rosenstock J, Jelaska A, Wang F et al. Empagliflozin as addon to basal insulin for 78 weeks improves glycemic control with weight loss in insulin-treated type 2 diabetes (T2DM). Can J Diabetes 2013;37:S32.

http://dx.doi.org/10.1016/j.jcjd.2013.08.093

57. Kadowaki T, Haneda M, Inagaki $\mathrm{N}$ et al. Empagliflozin monotherapy for 12 weeks improves glycemic control in Japanese patients with type 2 diabetes (T2DM). Abstract 1144-P presented at the 73rd Annual Scientific Sessions of the American Diabetes Association, June 21-25, Chicago, IL, USA. Diabetes 2013;62:A297-8.

58. Roden M, Weng J, Eilbracht J et al. Empagliflozin monotherapy with sitagliptin as an active comparator in patients with type 2 diabetes: a randomised, doubleblind, placebo-controlled, phase 3 trial. Lancet Diabetes Endocrinol 2013;1:208-19. http://dx.doi.org/10.1016/S2213-8587(13)70084-6

59. Kim Y, Babu AR. Clinical potential of sodium-glucose cotransporter 2 inhibitors in the management of type 2 diabetes. Diabetes Metab Syndr Obes 2012;5:313-27. http://dx.doi.org/10.2147/DMSO.S22545

60. Häring HU, Merker L, Seewaldt-Becker E et al. Empagliflozin as add-on to metformin in patients with type 2 diabetes: a 24-week, randomized, double-blind, placebo-controlled trial. Diabetes Care 2014;37:1650-9. http://dx.doi.org/10.2337/dc13-2105

61. Häring HU, Merker L, Seewaldt-Becker E et al. Empagliflozin as add-on to metformin plus sulfonylurea in patients with type 2 diabetes: a 24-week, randomized, double-blind, placebo-controlled trial. Diabetes Care 2013;36:3396-404. http://dx.doi.org/10.2337/dc12-2673

62. Kovacs CS, Seshiah V, Swallow R et al. Empagliflozin improves glycaemic and weight control as add-on therapy to pioglitazone or pioglitazone plus metformin in patients with type 2 diabetes: a 24-week, randomized, placebocontrolled trial. Diabetes Obes Metab 2013; 16:147-158. http://dx.doi.org/10.1111/dom.12188.

63. Barnett $A H$, Mithal A, Manassie J et al. Efficacy and safety of empagliflozin added to existing antidiabetes treatment in patients with type 2 diabetes and chronic kidney disease: a randomised, double-blind, placebo-controlled trial. Lancet Diabetes Endocrinol 2014;2:369-84. http://dx.doi.org/10.1016/S2213-8587(13)70208-0

64. Tikkanen I, Narko K, Zeller C et al. Empagliflozin improves blood pressure in patients with type 2 diabetes (T2DM) and hypertension. Abstract 942 presented at the 49th European Association for the Study of Diabetes Annual Meeting, September 23-27, Barcelona, Spain. Diabetologia 2013;56:S377.

65. Yale JF, Bakris G, Cariou B et al. Efficacy and safety of canagliflozin in subjects with type 2 diabetes and chronic kidney disease. Diabetes Obes Metab 2013;15:463-73. http://dx.doi.org/10.1111/dom.12090

66. Kohan DE, Fioretto P, Tang W, List JF. Long-term study of patients with type 2 diabetes and moderate renal impairment shows that dapagliflozin reduces weight and blood pressure but does not improve glycemic control. 
Kidney Int 2014;85:962-71. http://dx.doi.org/10.1038/ki.2013.356

67. Ridderstråle M, Svaerd R, Zeller C, Kim G, Woerle HJ, Broedl HC. Rationale, design and baseline characteristics of a 4-year (208-week) phase III trial of empagliflozin, an SGLT2 inhibitor, versus glimepiride as add-on to metformin in patients with type 2 diabetes mellitus with insufficient glycemic control. Cardiovasc Diabetol 2013;12:129. http://dx.doi.org/10.1186/1475-2840-12-129

68. Zinman B, Inzucchi SE, Lachin JM et al. Design of the empagliflozin cardiovascular (CV) outcome event trial in type 2 diabetes (T2D). Can J Diabetes 2013: 37:S29. http://dx.doi.org/10.1016/j.jcjd.2013.08.088

69. Rosebraugh CJ. Canagliflozin new drug application approval letter, 2013. Available at: www.accessdata.fda.gov/ drugsatfda_docs/appletter/2013/204042Orig1s000ltr.pdf (Last accessed March 24 2014).

70. Rosebraugh CJ. Dapagliflozin new drug application approval letter, 2014. Available at: www.accessdata.fda.gov/ drugsatfda_docs/appletter/2014/2022930rig1s000ltr.pdf (Last accessed March 24 2014).

71. Luippold G, Klein T, Mark M, Grempler R. Empagliflozin, a novel potent and selective SGLT-2 inhibitor, improves glycaemic control alone and in combination with insulin in streptozotocin-induced diabetic rats, a model of type 1 diabetes mellitus. Diabetes Obes Metab 2012;14:601-7. http://dx.doi.org/10.1111/j.1463-1326.2012.01569.x

72. Perkins BA, Cherney DZ, Partridge $\mathrm{H}$ et al. Sodium-glucose cotransporter 2 inhibition and glycemic control in type 1 diabetes: results of an 8-week open-label proof-of-concept trial. Diabetes Care 2014;37:1480-3.

http://dx.doi.org/10.2337/dc13-2338

73. Cherney DZ, Perkins BA, Soleymanlou N et al. Renal hemodynamic effect of sodium-glucose cotransporter 2 inhibition in patients with type 1 diabetes mellitus. Circulation 2014;129:587-97. http://dx.doi.org/10.1161/CIRCULATIONAHA.113.005081

74. Janssen Pharmaceuticals Inc. INVOKANA ${ }^{\mathrm{TM}}$ (canagliflozin) tablets, for oral use. Prescribing information,

2013. www.accessdata.fda.gov/drugsatfda_docs/ label/2013/204042s000lbl.pdf (Last accessed October 15 2013).

75. AstraZeneca Pharmaceuticals LP. FARXIGA ${ }^{\mathrm{TM}}$ (dapagliflozin) tablets, for oral use. Prescribing information, 2014. www.accessdata.fda.gov/drugsatfda_docs/ label/2014/202293s000lbl.pdf (Last accessed January 31 2014).

76. Garber AJ, Abrahamson MJ, Barzilay Jl et al. American Association of Clinical Endocrinologists' comprehensive diabetes management algorithm 2013 consensus statement--executive summary. Endocr Pract 2013;19: 536-57. http://dx.doi.org/10.4158/EP13176.CS

77. Inzucchi SE, Bergenstal RM, Buse JB et al. Management of hyperglycemia in type 2 diabetes: a patient-centered approach: position statement of the American Diabetes Association (ADA) and the European Association for the Study of Diabetes (EASD). Diabetes Care 2012;35: 1364-79. http://dx.doi.org/10.2337/dc12-0413 